\title{
二三雾角有効成分，超生蟇肝出糖 作用二及ボス影響
}

\author{
醫學士 安藤 憲司 \\ 醫學士一色征共述 \\ 醫學士田中實太郎 \\ (大阪醫科大學藥物學敎室〔主任 長崎钽授〕)
}

(昭和六年一月三十日受付)

\section{緒論}

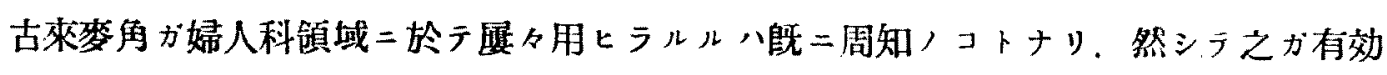

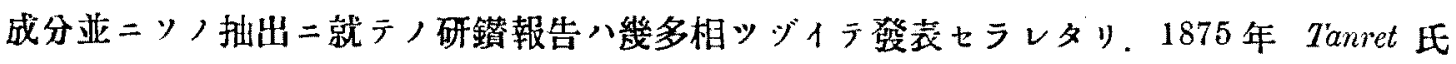

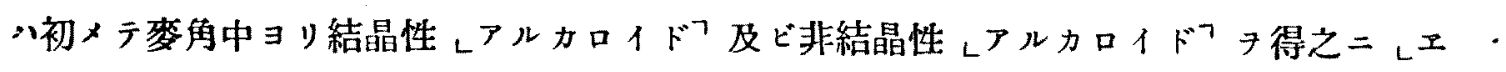
ルゴチニンフ皮ビ無晶形 レエルゴチニンフト命名セり。次デ 1906 年英國二於テ Barger, Carr, Dale 氏等八無晶形しエルゴチニンフォ分離シ, 瑞西二於テ Kraft 氏ハレヒドロエル ゴチニンフナル純粹ナルレアルカロイドフヨ抽出セり。サレド其後ノ研究ニヨり二者全ク

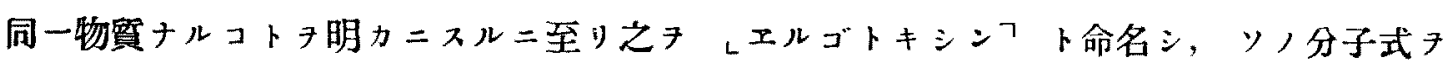
$\mathrm{C}_{35} \mathrm{H}_{41} \mathrm{~N}_{5} \mathrm{O}_{6}$ ト定メタリ。

1920 年 Stoll 氏ハ更ニーツノレアルカロイドフ 麥角中ヨリ發見シ之ョ Ergotamin ト稱セリ。ソノ作用モ亦しメルゴトキシンフ二類似シ, 分子式 $\mathrm{C}_{35} \mathrm{H}_{33} \mathrm{~N}_{5} \mathrm{O}_{5}+ル$ 結晶性物 䝷ナリト報告七リ。 叉 Barger, Dale 兩氏等八レェルゴトキシンー，外二少 しバラーヒド

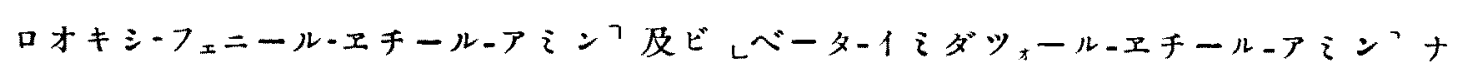

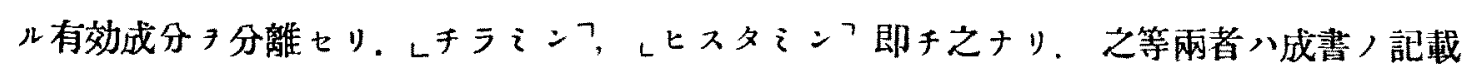

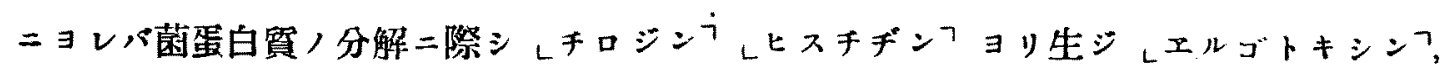

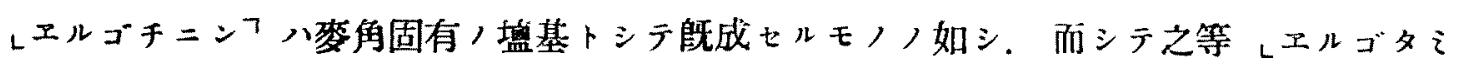

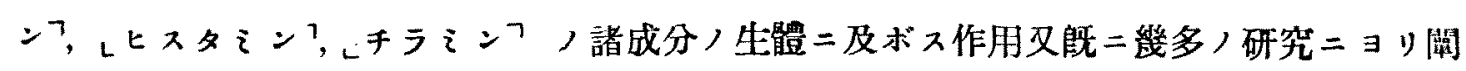
明七ラレタリ。就中䋨移動作用二就テモ亦多クノ報告アリ。サレド諸說未ダ歸一スル所ナ 
キノミナラズ，之等3成分，併用時二於タル糖移動作用二關シテハ明確ナル報告キ見ズ. 余等之二㘕え本問題，研究二着手七り。

\section{賽 驗 方 法}

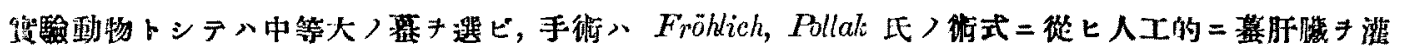

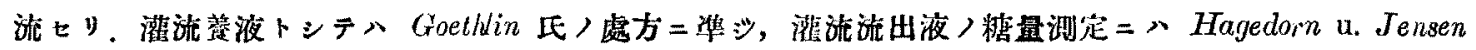
$\mathfrak{E}=\Xi$ Ferricyanid Methode 7 用ヒタリ。

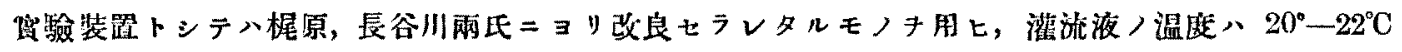

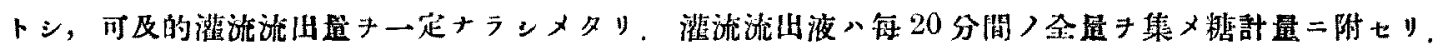

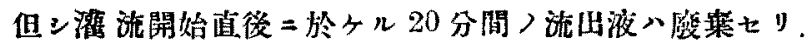

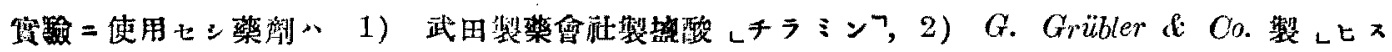

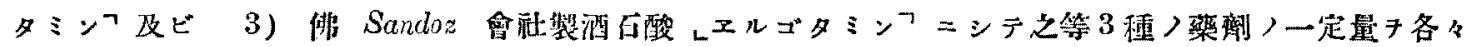

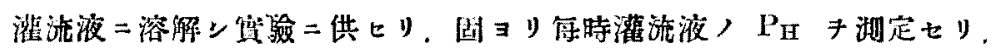

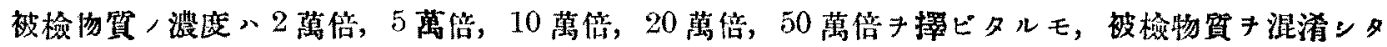

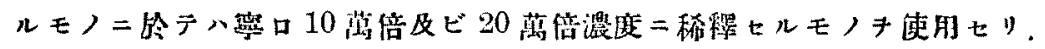

\section{實 驗 咸 綪}

\section{1. ᄂ上スタ ミンา}

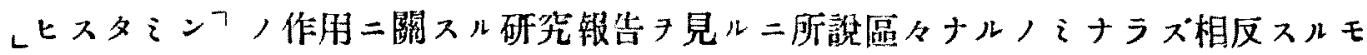
ノ亦少ナカラズ.

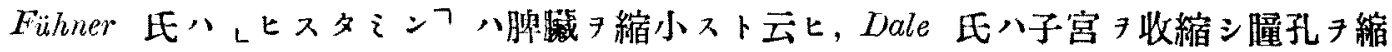

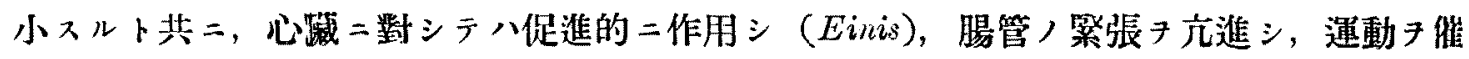

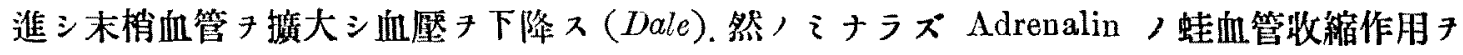
抑制入ト云フ (Handovsky). Fröhlich u. Pick, Börner, Dale，諸氏心レアドレナリンフ， 血厴上昇作用丹抑制スト云フ。

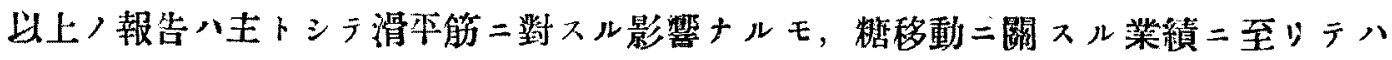

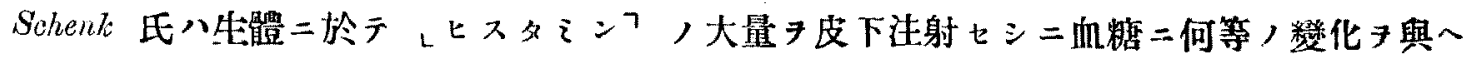
ズト.

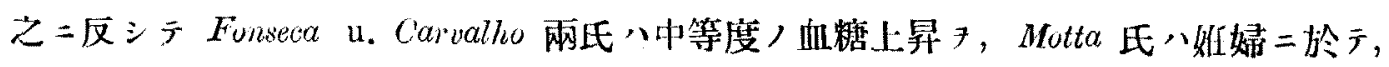

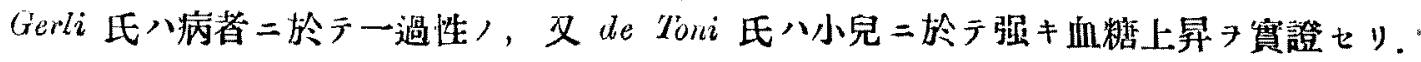




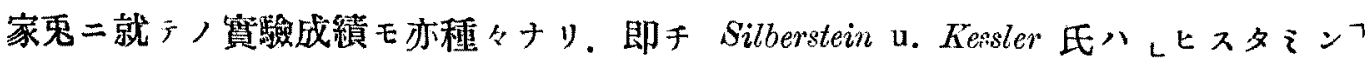
ニョリ血糖降下ヲ來スト。Cannavo 氏八飢餓家鬼二於テ，La Barre 氏八レモルモットᄀ

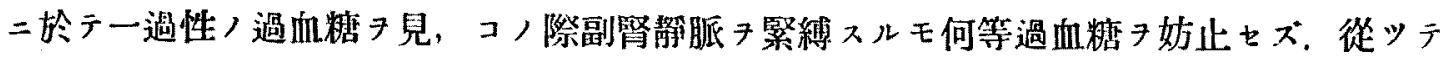

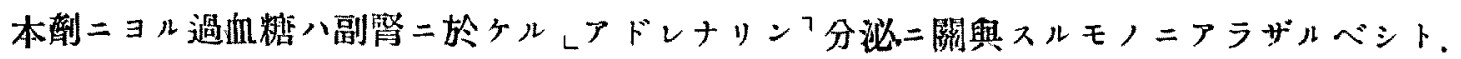

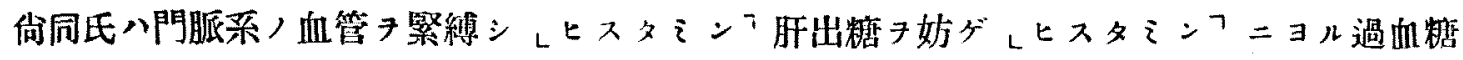
八肝瀻, レダリコダーンフ，流出二基因スト主晿セり。

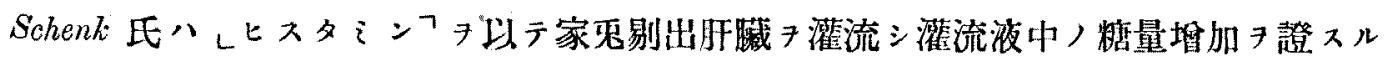

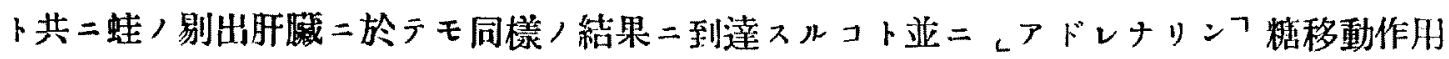

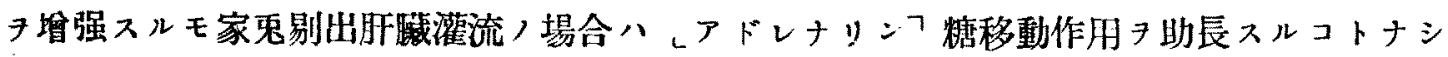

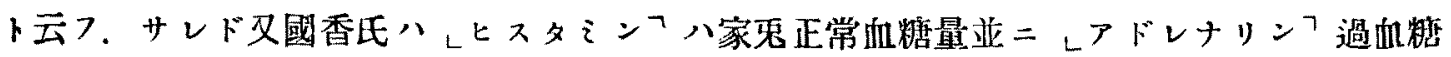
二何等ノ影揞 及ボサズト主張セリ。

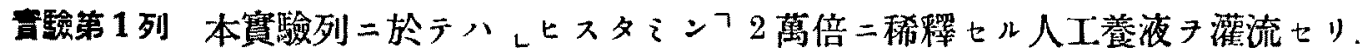
灌流順序八表中二記載七り。

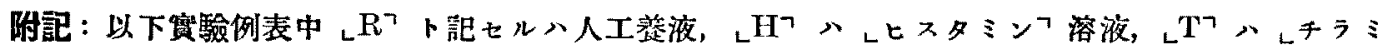

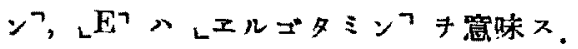

\section{第 1 表}

昭和 5 年. 7 月 1 日 液温 $21^{\circ} \mathrm{C}$

\begin{tabular}{|c|c|c|c|c|c|}
\hline 濩流液 & $\begin{array}{l}\text { 20分間 } \\
\text { 流出量 } \\
\text { (ccm) }\end{array}$ & $\begin{array}{l}\text { 1ccm } \\
\text { 中模量 } \\
\text { (mg) }\end{array}$ & $\begin{array}{c}\text { 肝 } 1 \mathrm{~g} \\
\text { 出掂量 } \\
\text { (mg) }\end{array}$ & 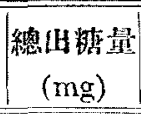 & $\begin{array}{c}\text { 旰重量 } \\
(\mathrm{g})\end{array}$ \\
\hline $\mathrm{R}$ & 109 & 0,020 & 0,436 & 2,180 & 5 \\
\hline $\mathrm{R}+\mathrm{H}$ & 102 & $0,03 \tilde{~}$ & 0,714 & 3,570 & \\
\hline $\mathrm{R}+\mathrm{H}$ & 108 & 0,030 & 0,648 & 3,240 & \\
\hline $\mathrm{R}$ & 108 & 0,026 & 0,562 & 2,808 & \\
\hline
\end{tabular}

\section{第 $\dot{2}$ 表}

昭和5年 6 月 25 日 液温 $21^{\circ} \mathrm{C}$

\begin{tabular}{|c|c|c|c|c|c|}
\hline 谁洗液 & 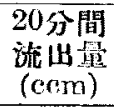 & 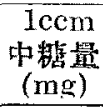 & 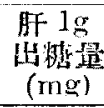 & 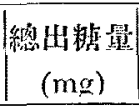 & $\begin{array}{c}\text { 肝重量 } \\
(\mathrm{g})\end{array}$ \\
\hline $\mathrm{R}$ & 93 & 0,029 & 0,449 & 2,697 & 6 \\
\hline $\mathrm{R}+\mathrm{H}$ & 95 & 0,049 & 0,775 & 4,655 & \\
\hline $\mathrm{R}+\mathrm{H}$ & 94 & 0,053 & 0,830 & 4,982 & \\
\hline $\mathrm{R}$ & 94 & 0,038 & 0,595 & 3,572 & \\
\hline
\end{tabular}
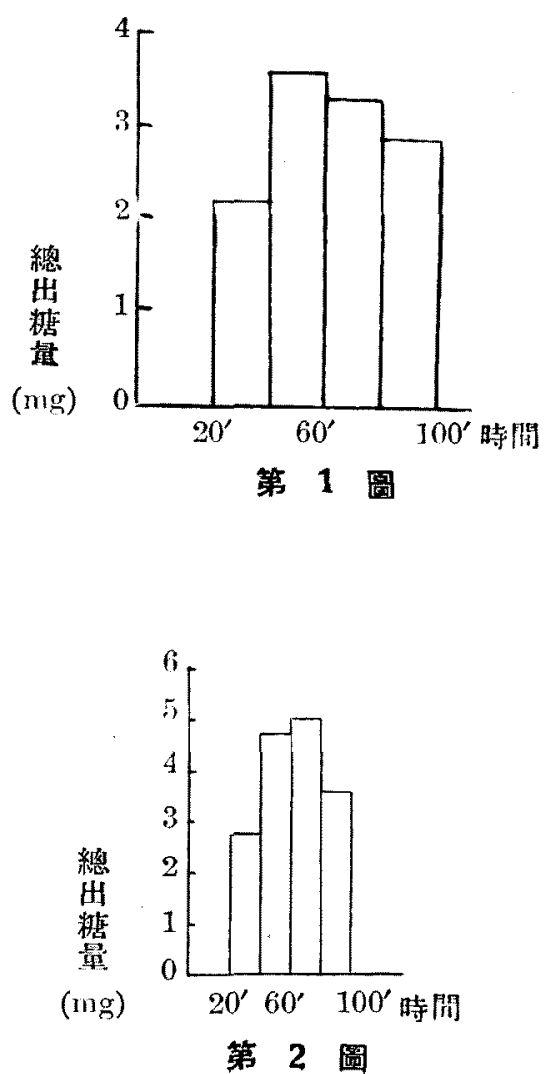
工驗第 2 列 本列二於テハ5 萬倍二稀釋セルレヒスタをンフ溶液ヨ灌流七リ。

第 3 吏

昭和 5 年 7 月 2 日 液溫 $21^{\circ} \mathrm{C}$

\begin{tabular}{|c|c|c|c|c|c|}
\hline 滥湤液 & $\begin{array}{l}20 \text { 分間 } \\
\text { 流出睹 } \\
(\mathrm{ccm})\end{array}$ & $\begin{array}{c}1 \mathrm{ccm} \\
\text { 中榶最 } \\
(\mathrm{mg})\end{array}$ & 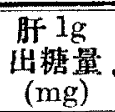 & 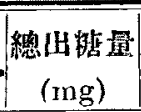 & $\begin{array}{c}\text { 肝重量 } \\
(\mathrm{g})\end{array}$ \\
\hline $\mathrm{R}$ & 104 & 0,058 & 0,431 & 6,032 & 14 \\
\hline $\mathrm{R}+\mathrm{H}$ & 106 & 0,055 & 0,417 & 5,830 & \\
\hline $\mathrm{R}+\mathrm{H}$ & 107 & 0,055 & 0,420 & 5,885 & \\
\hline $\mathrm{R}$ & 106 & 0,057 & 0,432 & 6,042 & \\
\hline
\end{tabular}

第 4 表

昭和 5 年 7 月 5 日 液温 $21^{\circ} \mathrm{C}$

\begin{tabular}{|c|c|c|c|c|c|}
\hline 灌流液 & $\begin{array}{l}20 \text { 分間 } \\
\text { 活出量 } \\
(\mathrm{ccm})\end{array}$ & $\begin{array}{c}\text { Iccm } \\
\text { 中榶篗 } \\
(\mathrm{mg})\end{array}$ & 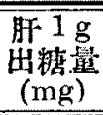 & $\begin{array}{c}\text { 稇出糖量 } \\
(\mathrm{mg} g)\end{array}$ & $\begin{array}{c}\text { 肝重量 } \\
(\mathrm{g})\end{array}$ \\
\hline $\mathbf{R}$ & 90 & 0,032 & 0,303 & 2,880 & 9,5 \\
\hline $\mathrm{R}+\mathrm{H}$ & 90 & 0,029 & 0,274 & 2,610 & \\
\hline $\mathrm{R}+\mathrm{H}$ & 88 & 0,034 & 0,315 & 2,992 & \\
\hline $\mathrm{R}$ & 92 & 0,032 & 0,310 & 2,944 & \\
\hline
\end{tabular}

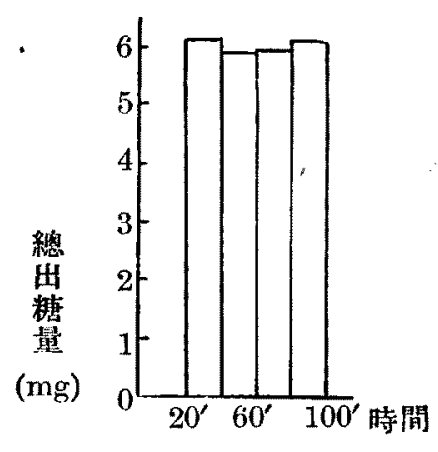

䒜 3 㘣.

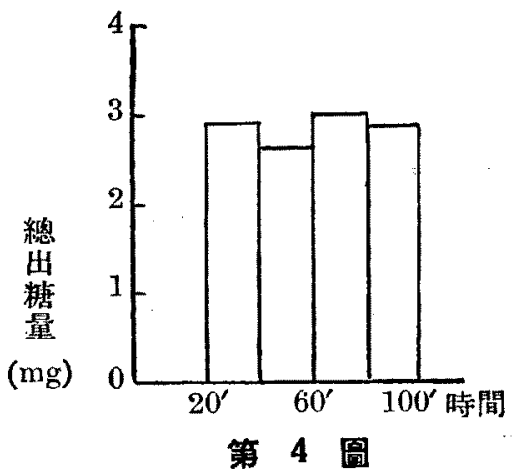

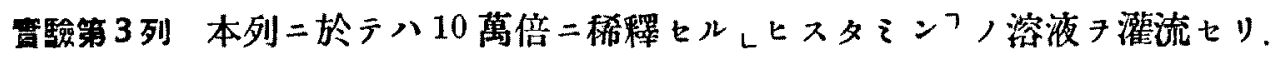

\section{第 5 表}

昭和 5 年 7 月 7 日 液温 $20^{\circ} \mathrm{C}$

\begin{tabular}{|c|c|c|c|c|c|}
\hline 濩流液 & $\begin{array}{l}20 \text { 分間 } \\
\text { 施计量 } \\
(\mathrm{ccm})\end{array}$ & 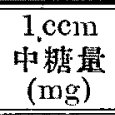 & 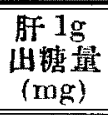 & $\begin{array}{c}\text { 總出辂量 } \\
(\mathrm{mg})\end{array}$ & $\begin{array}{c}\text { 肝重量 } \\
(\mathrm{g})\end{array}$ \\
\hline $\mathrm{R}$ & 98 & 0,037 & 0,426 & 3,626 & 8,5 \\
\hline $\mathrm{R}+\mathrm{H}$ & 95 & 0,035 & 0,392 & 3,325 & \\
\hline $\mathrm{R}+\mathrm{H}$ & 95 & 0,034 & 0,380 & 3,230 & \\
\hline $\mathrm{R}$ & 97 & 0,034 & 0,396 & 3,366 & \\
\hline
\end{tabular}

第 6 表

昭和 5 年 7 月 3 日 液温 $21^{\circ} \mathrm{C}$

\begin{tabular}{|c|c|c|c|c|c|}
\hline 整流液 & $\begin{array}{l}20 \text { 分闍 } \\
\text { 流仙量 } \\
\text { (ccm) } \\
\end{array}$ & $\begin{array}{c}1 \mathrm{ccm} \\
\text { 中蛅量 } \\
(\mathrm{mg}) \\
\end{array}$ & 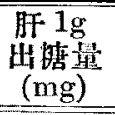 & $\begin{array}{c}\text { 稳仙煻量 } \\
(\mathrm{mg})\end{array}$ & $\begin{array}{c}\text { 肝重量 } \\
(\mathrm{g})\end{array}$ \\
\hline $\mathbf{R}$ & 101 & 0,024 & 0,447 & 2,424 & 5,5 \\
\hline $\mathrm{R}+\mathrm{II}$ & 103 & 0,020 & 0,375 & 2,060 & \\
\hline $\mathrm{R}+\mathrm{H}$ & 104 & 0,020 & 0,378 & 2,080 & \\
\hline $\mathrm{R}$ & 109 & 0,022 & 0.436 & 2,398 & \\
\hline
\end{tabular}
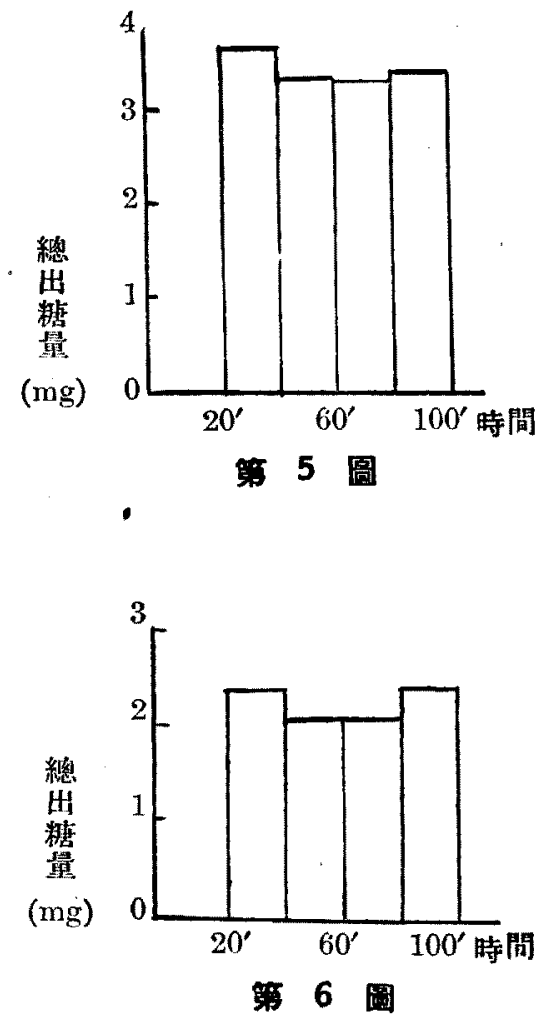


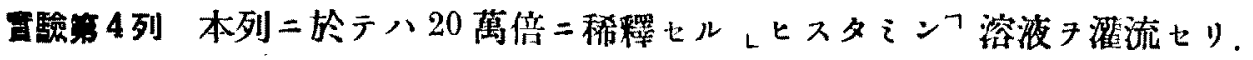

第 7 表

昭和 5 年 7 月 4 日 液温 $21^{\circ} \mathrm{C}$

\begin{tabular}{|c|c|c|c|c|c|}
\hline 灌流液 & $\begin{array}{l}20 \text { 分間 } \\
\text { 流估量 } \\
\text { (ccm) }\end{array}$ & $\begin{array}{c}\text { 1ccm } \\
\text { 中溏量 } \\
\text { (mg) }\end{array}$ & $\begin{array}{c}\text { 奛 } 1 \mathrm{~g} \\
\text { 出榶谱 } \\
\text { (mg) }\end{array}$ & $\left|\begin{array}{c}\text { 穆仙榶量 } \\
(\mathrm{mg})\end{array}\right|$ & $\begin{array}{c}\text { 肝重量 } \\
(\mathrm{g})\end{array}$ \\
\hline $\mathbf{R}$ & 91 & 0,025 & 0,455 & 2,275 & 5 \\
\hline $\mathrm{R}+\mathrm{H}$ & 92 & 0,023 & 0,423 & 2,116 & \\
\hline $\mathrm{R}+\mathrm{H}$ & 93 & 0,023 & 0,428 & 2,139 & \\
\hline $\mathbf{R}$ & 92 & 0,023 & 0,423 & 2,119 & \\
\hline
\end{tabular}

第 8

昭和 5 年 7 月 6 日 液温 $20^{\circ} \mathrm{C}$

\begin{tabular}{|c|c|c|c|c|c|}
\hline 灌流液 & $\begin{array}{l}20 \text { 分䦔 } \\
\text { 流出量 } \\
(\mathrm{ccm})\end{array}$ & $\begin{array}{l}1 \mathrm{ccm} \\
\text { 中糖量 } \\
(\mathrm{mg})\end{array}$ & 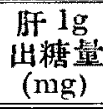 & $\begin{array}{c}\text { 繌出搪量 } \\
(\mathrm{mg})\end{array}$ & $\begin{array}{c}\text { 肝重量 } \\
\text { (g) }\end{array}$ \\
\hline $\mathrm{R}$ & 95 & 0,023 & 0,486 & 2,185 & 4,5 \\
\hline $\mathbf{R}+\mathbf{H}$ & 92 & 0,025 & 0,511 & 2,300 & \\
\hline $\mathrm{R}+\mathrm{H}$ & 95 & 0,023 & 0,486 & 2,185 & \\
\hline $\mathrm{R}$ & 92 & 0,021 & 0,429 & 1,932 & \\
\hline
\end{tabular}
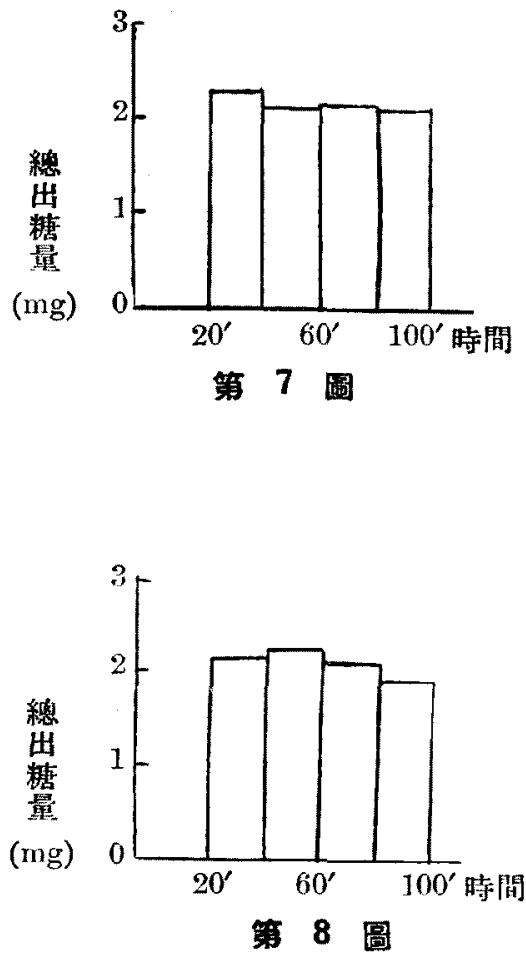

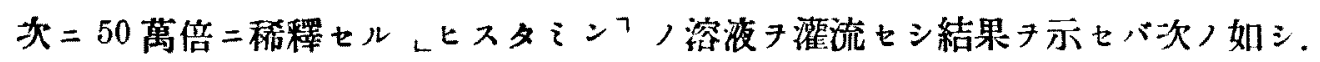

筆 9 表

昭和 5 年 7 月 9 日 没温 $20^{\circ} \mathrm{C}$

\begin{tabular}{|c|c|c|c|c|c|}
\hline 灌流液 & $\begin{array}{l}20 \text { 分䦔 } \\
\text { 流出量 } \\
\text { (ccm) }\end{array}$ & $\begin{array}{l}\text { lccin } \\
\text { 中糖量 } \\
\text { (mg) } \\
\end{array}$ & $\begin{array}{c}\text { 肝 } 1 g \\
\text { 出榶量 } \\
\text { (mg) } \\
\end{array}$ & 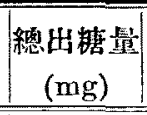 & $\begin{array}{c}\text { 㿞重量 } \\
(\mathrm{g})\end{array}$ \\
\hline $\mathrm{R}$ & 91 & $0,019^{\circ}$ & 0,865 & 1,729 & 2 \\
\hline $\mathrm{R}+\mathrm{H}$ & 91 & 0,019 & 0,865 & 1,729 & \\
\hline $\mathrm{R}+\mathrm{H}$ & 90 & 0,019 & 0,855 & 1,710 & \\
\hline $\mathrm{R}$ & 92 & 0,017 & 0,782 & 1,564 & \\
\hline
\end{tabular}

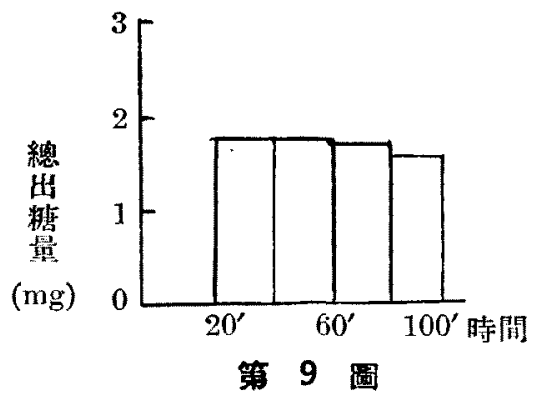

\section{考察}

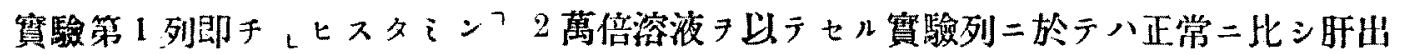

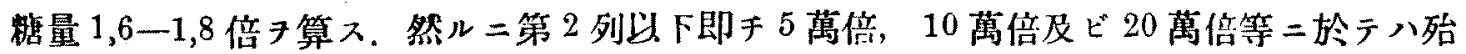
ンド總テニ於テ正常榶量以上ニ出ズル事ナク寧口待々正常量ヨリモ僅カ二低下七ル感アリ。 
少 50 萬倍二於テハ何等認ムべネ作用ョ星セボ.

\section{2. レチラ シ ンフ}

レチラミンフ，藥物學的作用八 Dale u. Diron 雨氏ニヨリテ初メテ研究七ラレタリ。

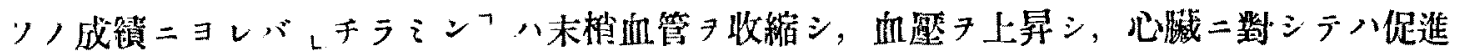

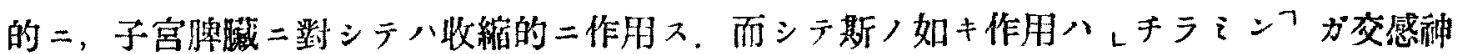

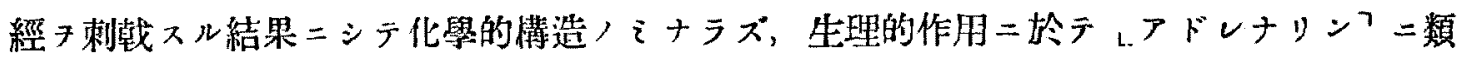

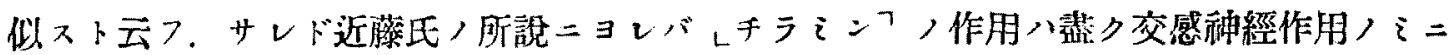
テハ䛺明シ能ハザルモ゙ノアル如シ。

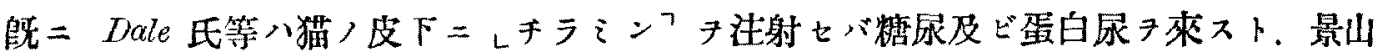

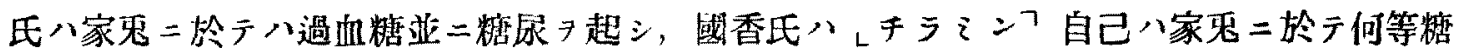
移動作朋ヲ起サザルモ、レフドレナリンフト併用スレバ著明ナル䌅移動作用アリト云フ。西

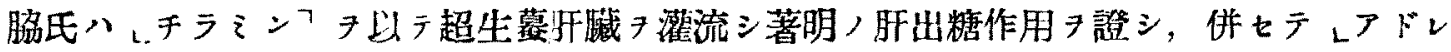
ナリンフ肝出糖二墨シテハ何等影響 $タ$ 興へズト云へリ.

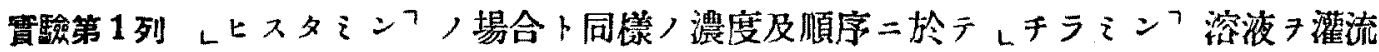
セリ，即チ本列二於テハレキラミンフ，濃度 2 萬倍ナリ。

\section{第 10 表}

昭和 5 年 7 月 11 日 液温 $20^{\circ} \mathrm{C}$

\begin{tabular}{|c|c|c|c|c|c|}
\hline 灌流液 & $\begin{array}{l}20 \text { 分間 } \\
\text { 流出量 } \\
(\mathrm{ccm})\end{array}$ & $\begin{array}{l}1 \mathrm{ccm} \\
\text { 中楛量 } \\
\text { (mg) }\end{array}$ & 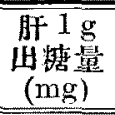 & 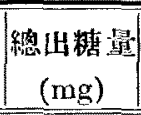 & $\begin{array}{c}\text { 肝重量 } \\
(\mathrm{g})\end{array}$ \\
\hline $\mathrm{R}$ & 97 & 0,037 & 0,355 & 3,589 & 10,1 \\
\hline$R+T$ & 96 & 0,078 & 0,741 & 7,494 & \\
\hline $\mathrm{R}+\mathrm{T}$ & 96 & 0,076 & 0,722 & 7,296 & \\
\hline $\mathrm{R}$ & 98 & 0,046 & 0,446 & 4,508 & \\
\hline
\end{tabular}

第 11 表

昭和 5 年 7 月 8 日 液温 $20^{\circ} \mathrm{C}$

\begin{tabular}{|c|c|c|c|c|c|}
\hline 灌流液 & 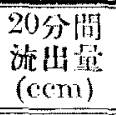 & $\begin{array}{c}1 \mathrm{cem} \\
\text { W粘量 } \\
(\mathrm{mg}) \\
\end{array}$ & $\begin{array}{l}\text { 肝 } 1 \mathrm{~g} \\
\text { 崖䌅量 } \\
\text { (mg) }\end{array}$ & $\begin{array}{c}\text { 總比阽量 } \\
(\mathrm{mg})\end{array}$ & $\begin{array}{c}\text { 肝重量 } \\
(\mathrm{g}) \\
\end{array}$ \\
\hline $\mathrm{R}$ & 90 & 0,025 & 0,750 & 2,250 & 3 \\
\hline $\mathbf{R}+\mathbf{T}$ & 90 & 0,064 & 1,920 & 5,760 & \\
\hline $\mathrm{P}+\mathrm{T}$ & 89 & 0,064 & 1,899 & 5,696 & \\
\hline $\mathrm{R}$ & 89 & 0,035 & 1,038 & 3,115 & \\
\hline
\end{tabular}

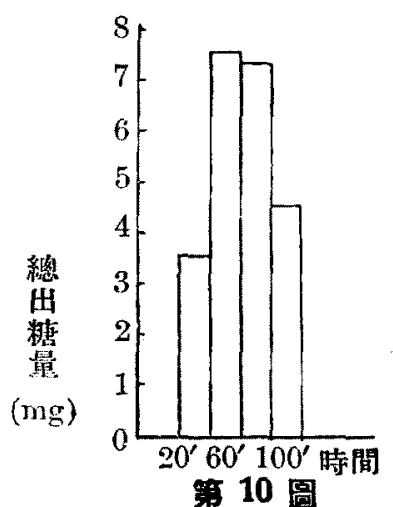

10 圆

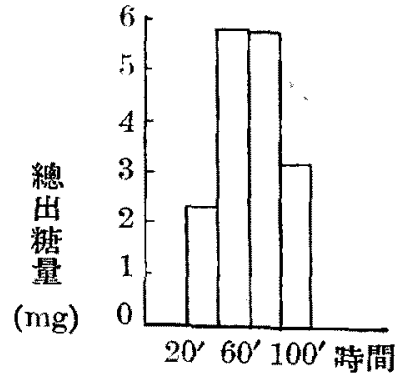

第 11 圖 
可駼第 2 列 ᄂチラランフ，濃度 5 萬倍溶波灌流。

苐 12 表

沿和 5 年 7 月 12 日 液温 $21^{\circ} \mathrm{C}$

\begin{tabular}{|c|c|c|c|c|c|}
\hline 灌流液 & $\begin{array}{l}\begin{array}{l}20 \text { 分闍 } \\
\text { 流埴 } \\
(\mathrm{ccm})\end{array} \\
\end{array}$ & $\begin{array}{c}1 \mathrm{ccm} \\
\text { 中糖量 } \\
(\mathrm{mg}) \\
\end{array}$ & $\begin{array}{l}\text { 䏦 } 1 \mathrm{~g} \\
\text { 出糖量 } \\
(\mathrm{mg}) \\
\end{array}$ & 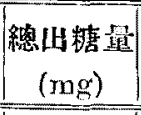 & $\begin{array}{c}\text { 肝重量 } \\
(\mathrm{g}) \\
\end{array}$ \\
\hline$R$ & 96 & 0,029 & 0,371 & 2,784 & 7,5 \\
\hline$R+T$ & 98 & 0,040 & 0,523 & 3,920 & \\
\hline$R+T$ & 95 & 0,040 & 0,507 & 3,800 & \\
\hline $\mathbf{R}$ & 96 & 0,026 & 0,333 & 2,496 & \\
\hline
\end{tabular}

第 13 串

昭和 5 年 7 月 20 日 液温 $21^{\circ} \mathrm{C}$

\begin{tabular}{|c|c|c|c|c|c|}
\hline 灌游液 & $\begin{array}{l}20 \text { 分間 } \\
\text { 流贯 } \\
(\mathrm{ccm})\end{array}$ & $\begin{array}{l}1 \mathrm{ccm} \\
\text { 中糖望 } \\
\text { (mg) }\end{array}$ & 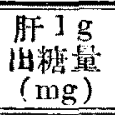 & $\begin{array}{c}\text { 總出磧量 } \\
(\mathrm{mg})\end{array}$ & $\begin{array}{c}\text { 旰重量 } \\
(\mathrm{g})\end{array}$ \\
\hline $\mathrm{R}$ & 92 & 0,022 & 0,450 & 2,024 & 4,5 \\
\hline$R+T$ & 94 & 0,035 & 0,731 & 3,290 & \\
\hline$R+T$ & 92 & 0,037 & 0,756 & 3,404 & \\
\hline $\mathrm{R}$ & 94 & 0,021 & 0,439 & 1,974 & \\
\hline
\end{tabular}

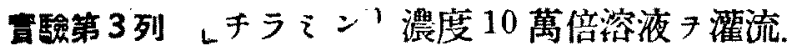

第 14 表

昭和 5 年 7 月 18 日 落温 $20^{\circ} \mathrm{C}$

\begin{tabular}{|c|c|c|c|c|c|}
\hline 灌流液 & $\begin{array}{l}20 \text { 分間 } \\
\text { 流红量 } \\
\text { (ccon) } \\
\end{array}$ & $\begin{array}{c}1 \mathrm{ccma} \\
\text { 中糖量 } \\
(\mathrm{mg})\end{array}$ & 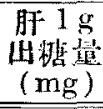 & 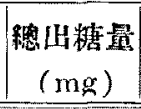 & $\begin{array}{c}\text { 肝重墔 } \\
(\mathrm{g})\end{array}$ \\
\hline $\mathrm{R}$ & 104 & 0,024 & 0,554 & 2,496 & 4,5 \\
\hline$R+T$ & 102 & 0,035 & 0,793 & 3,570 & \\
\hline$R+T$ & 104 & 0,034 & 0,786 & 3,536 & \\
\hline $\mathbf{R}$ & 102 & 0,024 & 0,544 & 2,448 & \\
\hline
\end{tabular}

第 15 表

昭和 5 年 7 月 16 日 液温 $20^{\circ} \mathrm{C}$

\begin{tabular}{|c|c|c|c|c|c|}
\hline 灌流液 & $\begin{array}{l}20 \text { 分得 } \\
\text { 流仙最 } \\
(\mathrm{ccm})\end{array}$ & $\begin{array}{l}1 \mathrm{com} \\
\text { 中势量 } \\
(\mathrm{mg}) \\
\end{array}$ & $\begin{array}{c}\text { 肝 } 1 \mathrm{~g} \\
\text { 出糖曼 } \\
(\mathrm{mg}) \\
\end{array}$ & $\begin{array}{c}\text { 唯出煻最 } \\
(\mathrm{mg})\end{array}$ & $\begin{array}{c}\text { 豚重量 } \\
(\mathrm{g}) \\
\end{array}$ \\
\hline $\mathrm{R}$ & 96 & 0,056 & 0,827 & 5,376 & 6,5 \\
\hline$R+T$ & 95 & 0,073 & 1,067 & 6,985 & \\
\hline $\mathbf{R}+\mathbf{T}$ & 95 & 0,068 & 0,993 & 6,460 & \\
\hline $\mathrm{R}$ & 95 & 0,058 & $.0,805$ & 5,510 & \\
\hline
\end{tabular}
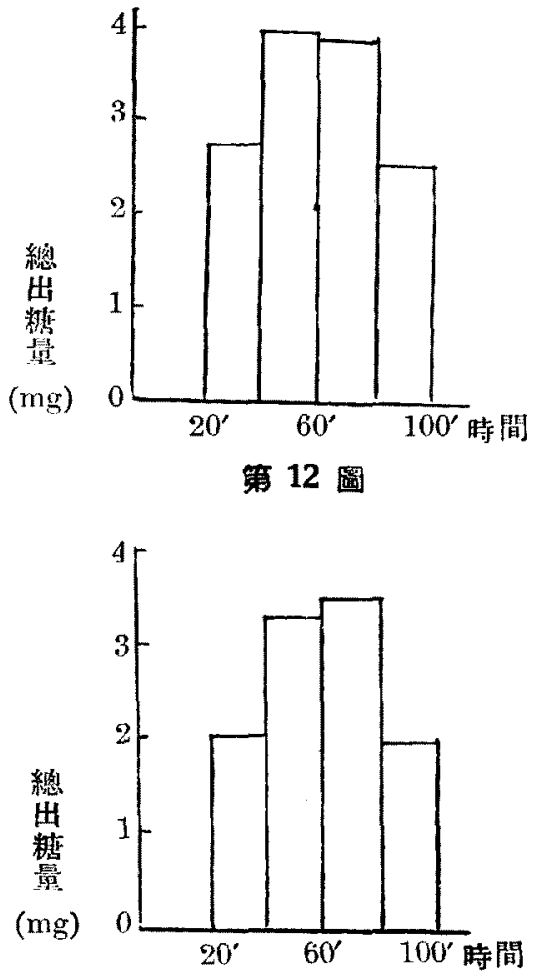

第 13 圆

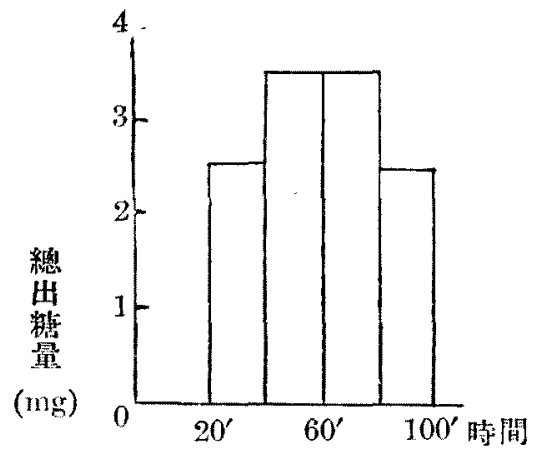

第 14 圆

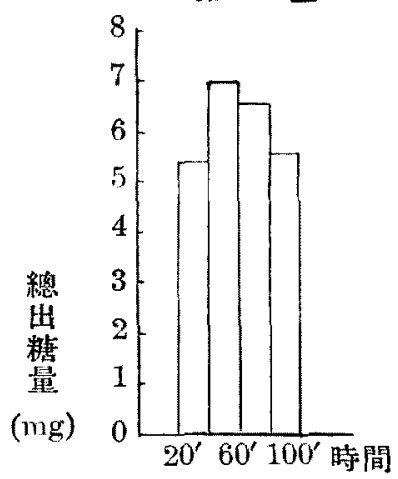

䒜 15 圖 
驗第 3 列 レチラそンフ 濃度 20 萬倍溶液灌流.

\section{第 16 表}

昭和 5 年 7 月 14 日 液温 $20^{\circ} \mathrm{C}$

\begin{tabular}{|c|c|c|c|c|c|}
\hline 政流液 & $\begin{array}{l}20 \text { 分間 } \\
\text { 流计䭪 } \\
\text { (ccm) }\end{array}$ & $\begin{array}{l}1 \mathrm{ccm} \\
\text { 中糖量 } \\
\text { (mg) }\end{array}$ & $\begin{array}{l}\text { 奣 } 1 \mathrm{~g} \\
\text { 出榶量 } \\
(\mathrm{mg})\end{array}$ & $\begin{array}{c}\text { 總出话量 } \\
(\mathrm{mg})\end{array}$ & $\begin{array}{c}\text { 旰重墔 } \\
(\mathrm{g})\end{array}$ \\
\hline $\mathrm{R}$ & 96 & 0,021 & 0,806 & 2,016 & 2,5 \\
\hline $\mathbf{R}+\mathbf{T}$ & 94 & 0,028 & 1,052 & 2,632 & \\
\hline $\mathbf{R}+\mathbf{T}$ & 96 & 0,026 & 0,998 & 2,496 & \\
\hline $\mathrm{R}$ & 96 & 0,021 & 0.806 & 2,016 & \\
\hline
\end{tabular}

第 17 表

昭和 5 年 7 月 15 日 液温 $21^{\circ} \mathrm{C}$

\begin{tabular}{|c|c|c|c|c|c|}
\hline 瀖流液 & $\begin{array}{l}20 \text { 分間 } \\
\text { 流出量 } \\
(\mathrm{ccm})\end{array}$ & $\begin{array}{c}1 \mathrm{ccm} \\
\text { 中糖唱 } \\
(\mathrm{mg}) \\
\end{array}$ & 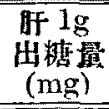 & $\begin{array}{c}\text { 總出榶量 } \\
(\mathrm{mg})\end{array}$ & $\begin{array}{c}\text { 肝重 } \\
(g)\end{array}$ \\
\hline $\mathbf{R}$ & 95 & 0,042 & 0,886 & 3,990 & 4,5 \\
\hline$R+T$ & 94 & 0,049 & 1,023 & 4,606 & \\
\hline $\mathbf{R}+\mathbf{T}$ & 94 & 0,052 & 1,086 & 4,888 & \\
\hline $\mathrm{R}$ & 92 & 0,047 & 0,960 & 4,324 & \\
\hline
\end{tabular}

督驗第 4 列 レチラミンフ 濃度 50 萬倍溶液灌流

\section{第 18 表}

昭和 5 年 7 月 13 日 液温 $20^{\circ} \mathrm{C}$

\begin{tabular}{|c|c|c|c|c|c|}
\hline 整施液 & $\begin{array}{l}20 \text { 分间 } \\
\text { 流山悬 } \\
\text { (ccm) }\end{array}$ & $\begin{array}{c}1 \mathrm{ccm} \\
\text { p榶量 } \\
(\mathrm{mg}) \\
\end{array}$ & 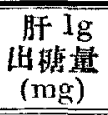 & $\begin{array}{c}\text { 總出塘星 } \\
(\mathrm{mg})\end{array}$ & 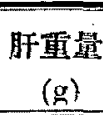 \\
\hline $\mathrm{R}$ & 93 & 0,024 & 0,531 & 2,232 & 4,2 \\
\hline $\mathrm{R}+\mathrm{T}$ & 93 & 0,024 & 0,531 & 2,232 & \\
\hline $\mathrm{R}+\mathrm{T}$ & 91 & 0,026 & 0,563 & 2,366 & \\
\hline $\mathrm{R}$ & 94 & 0,024 & 0,537 & 2,256 & \\
\hline
\end{tabular}

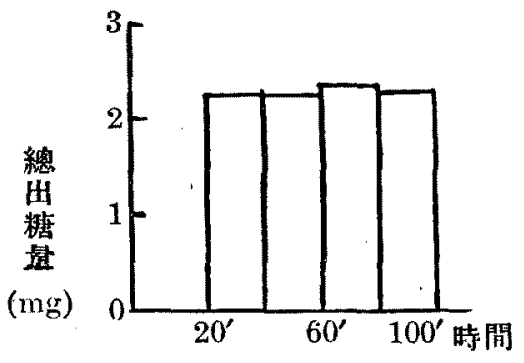

第 18 圆

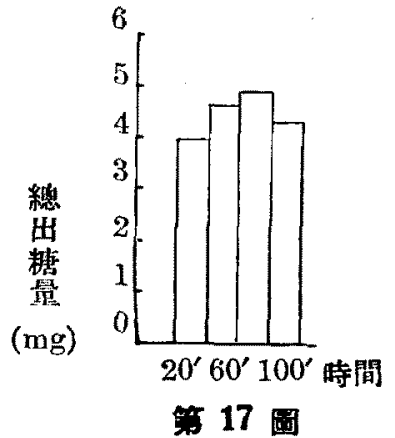

\section{考察}




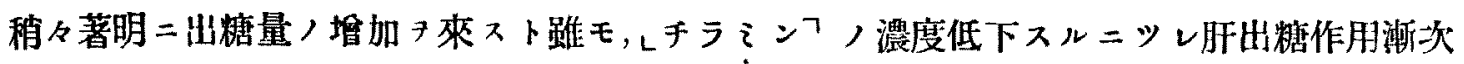
微弱トナリ，既二濃度 50 萬倍二至レバ殆ンドソノ作用キ認ムル能ハズ.

\section{3. レエルゴタミン}

レエルゴダンフハェエルゴトキシンフ二類似シ Dale u. Spiro 兩氏，賔驗二依レバ 殆ンドソノ作用㥵等シト云フ。

而シテレエルゴトキシンフ，顯著ナル作用ハ交感神經鼠揞二由來スル子宮收縮及ビ末 梢血管收縮等ナリトス，又一般ニょエルゴトキシンフハレアドレナリンフト拮抗性二作用 スルモノト稱セラル. Fröhlich u. Pollak 八冷血動物，剔出肝藏二就キテ實驗シ，同一結

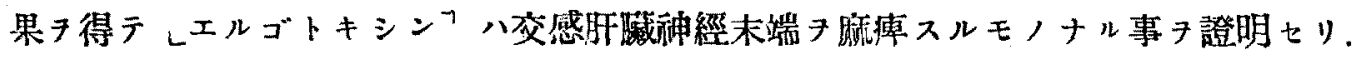

1921 年 $K$. Spiro u. A. Stoll 雨氏ハレエルゴタミンフノ藥物學的檢索テ行ヒ, モルモ

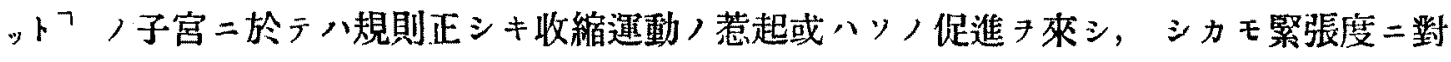
シテハ不規則的二影響スルモノナリト云フ. 炎レエルゴタンフハ末梢血管二對シテハレエ

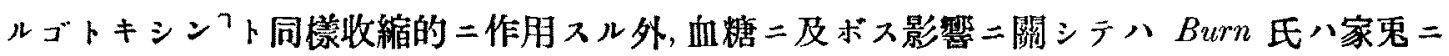
於テレアドレナリンフ過血糖ヨ抑制シ且又小量八レインズリンフ，作用ヨ著シク充進ス ト. Miculicich, Laurin，國香ノ諸氏又之二賛ス。更二レエルゴダンフ，血糖降下作用八 Lesser u. Zipf，(家鬼），Seidel（家鬼及ビ糖尿病亚二ばせミ゙う氏病患者）Loeffler，Moretti 等諸家ノ等シク認ムルトコロナリ. 然ルニ Silberstein u. Kessler 兩氏ハレエルゴタネンフ

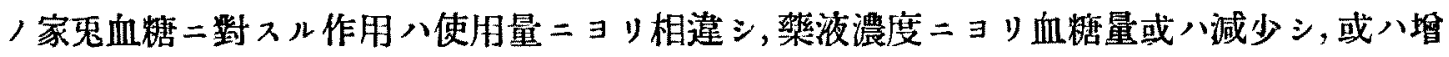
加ス.レ.インズリンフトノ併用ノ際二於テモレエルゴダンフ小量ノ場合ハ血糖降下作用延 長スルモ，大量ハレインズリンフ，作用 $フ$ 減弱シ，初期血糖上昇キ來スト論ゼリ。Rigo u. Veszelsky 兩氏双コレタ支持ス. Steiner 氏ハ小兒二ムギネルゲンフ注射後血糖量 $=4$ 種ノ變

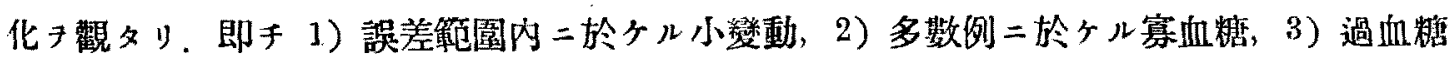
及ビ 4) 不規則ナル動搖等之レナリ.

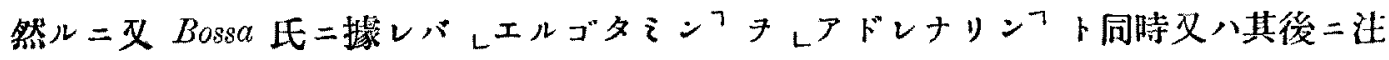

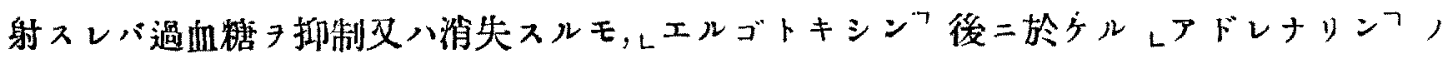

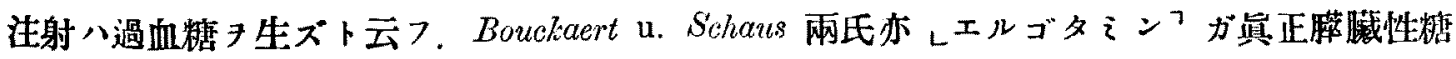
尿㞫ニハ殆ンド無效ナルコトタ報告セり。

Rothlin 氏ハ义家鬼正常血榶ハ上エルゴタミンフニヨリ變化セズト云ヒ，Cannavo 氏 


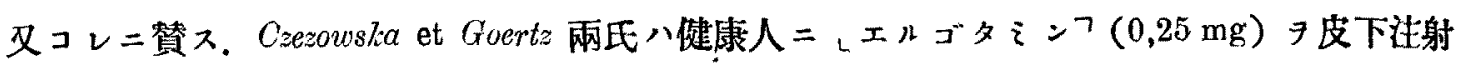

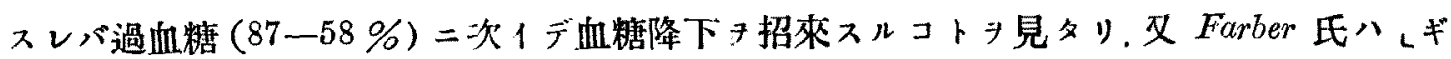

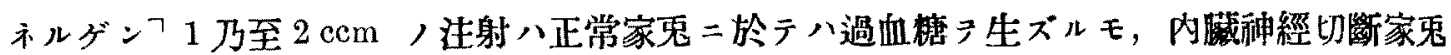
二於テハ却ツテ塞血糖子招來入ト主張セり，

以上記述七ル如クレエルゴタミンフノ血糖二及ボス影響八諸家ノ報告未ダ全ク一致スル

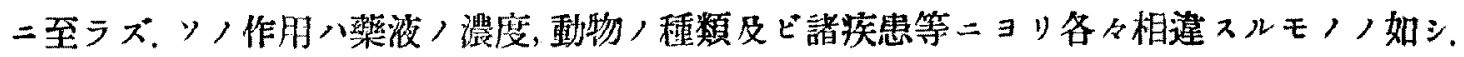

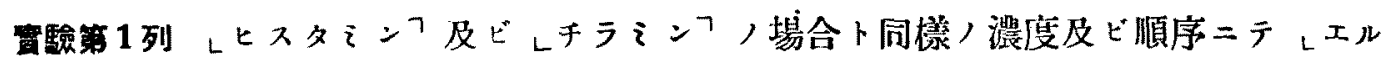

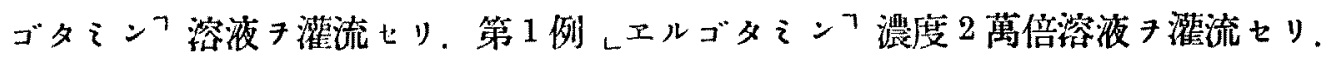

第 19 表

昭和 5 年 7 月 17 日 没溫 $21^{\circ} \mathrm{C}$

\begin{tabular}{|c|c|c|c|c|c|}
\hline 筑流液 & $\begin{array}{l}20 \text { 分間 } \\
\text { 流㨁晴 } \\
(\mathrm{ccm})\end{array}$ & $\begin{array}{c}\text { 1ccm } \\
\text { 中糖喤 } \\
\text { (mg) }\end{array}$ & $\begin{array}{c}\text { ffflg } \\
\text { 出榶量 } \\
(\mathrm{mg}) \\
\end{array}$ & $\begin{array}{c}\mid \begin{array}{c}\text { 總出糖䭪 } \\
(\mathrm{mg})\end{array} \\
\end{array}$ & $\begin{array}{c}\text { 肝重量 } \\
(\mathrm{g}) \\
\end{array}$ \\
\hline $\mathbf{R}$ & 90 & 49 & 0,678 & 4,410 & 6,5 \\
\hline $\mathbf{R}+\mathbf{T}$ & 91 & 94 & 1,316 & 8,554 & \\
\hline $\mathbf{R}+\mathbf{T}$ & 92 & 92 & 1,302 & 8,464 & \\
\hline $\mathrm{R}$ & 90 & 53 & 0,734 & 4,770 & \\
\hline
\end{tabular}

第 20 表

昭和 5 年 7 月 19 日 液温 $21^{\circ} \mathrm{C}$

\begin{tabular}{|c|c|c|c|c|c|}
\hline 㔈流液 & $\begin{array}{l}20 \text { 分間 } \\
\text { 流出量 } \\
(\mathrm{ccm})\end{array}$ & $\begin{array}{c}\text { 1 ccm } \\
\text { 中椋量 } \\
\text { (mg) }\end{array}$ & $\begin{array}{l}\text { 奣 } 1 \mathrm{~g} \\
\text { 出裾量 } \\
(\mathrm{mg})\end{array}$ & $\begin{array}{c}\text { 總出䅯量 } \\
(\mathrm{mg})\end{array}$ & $\begin{array}{c}\text { 肝重量 } \\
(g)\end{array}$ \\
\hline$R$ & 99 & 0,042 & 0,695 & 4,158 & 6 \\
\hline $\mathrm{R}+\mathrm{H}$ & 97 & 0,080 & 1,293 & 7,760 & \\
\hline $\mathrm{R}+\mathrm{H}$ & 97 & 0,085 & 1,374 & 8,245 & \\
\hline $\mathbf{R}$ & 98 & 0,052 & 0,849 & 5,096 & \\
\hline
\end{tabular}

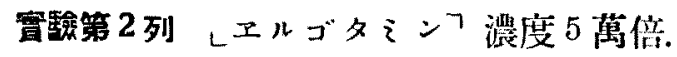

第 21 表

昭和 5 年 7 月 21 日 液温 $20^{\circ} \mathrm{C}$

\begin{tabular}{|c|c|c|c|c|c|}
\hline 㸆游液 & $\begin{array}{l}20 \text { 分間 } \\
\text { 流出量 } \\
\text { (ccm) } \\
\end{array}$ & $\begin{array}{c}1 \mathrm{ccm} \\
\text { 中淿量 } \\
(\mathrm{mg}) \\
\end{array}$ & $\begin{array}{c}\text { 朝 } 1 \mathrm{~g} \\
\text { 出䉼量 } \\
(\mathrm{mg}) \\
\end{array}$ & $\begin{array}{c}\text { 總出椋量 } \\
(\mathrm{mm})\end{array}$ & $\begin{array}{l}\text { 旰重点: } \\
(\mathrm{g}) \\
\end{array}$ \\
\hline $\mathrm{R}$ & 90 & 0,038 & 0,760 & 3,420 & 4,5 \\
\hline$R+T$ & 89 & 0,054 & 1,068 & 4,806 & \\
\hline $\mathrm{R}+\mathrm{T}$ & 91 & 0,056 & 1,132 & 5,096 & \\
\hline$R$ & 91 & 0,041 & 0,829 & 3,731 & \\
\hline
\end{tabular}
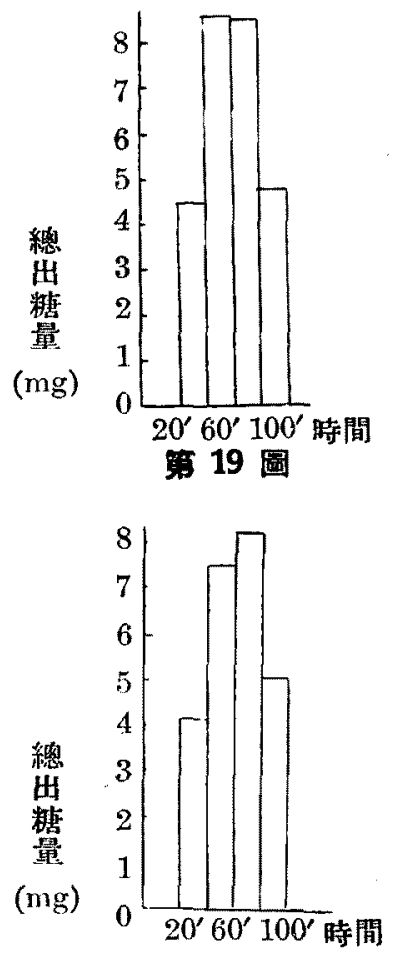

第 20 圆

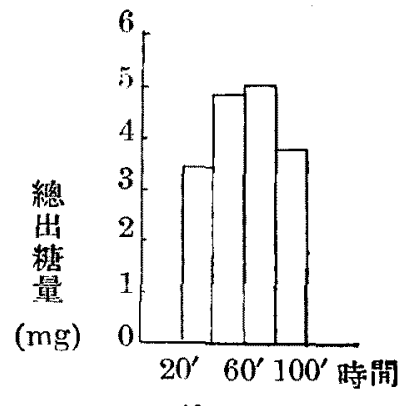

苇 21 圖 
第 22 表

昭和 5 年 7 月 22 日 腹榅 $20^{\circ} \mathrm{C}$

\begin{tabular}{|c|c|c|c|c|c|}
\hline 淮湤液 & $\begin{array}{l}20 \text { 分間 } \\
\text { 流旦量 } \\
(\mathrm{ccm})\end{array}$ & $\begin{array}{c}\text { 1ccm } \\
\text { 中榶量 } \\
(\mathrm{mg})\end{array}$ & $\begin{array}{c}\text { 橗 } 1 g \\
\text { 出糖量 } \\
\text { (mg) }\end{array}$ & $\mid \begin{array}{c}\text { 總出枯是 } \\
(\mathrm{mg})\end{array}$ & $\begin{array}{c}\text { 肝重量 } \\
(\mathrm{g}) \\
\end{array}$ \\
\hline $\mathrm{R}$ & 96 & 0,048 & 0,743 & 4,608 & 6,2 \\
\hline $\mathbf{R}+\mathbf{E}$ & 94 & 0,066 & 1,001 & 6,204 & \\
\hline$R+T$ & 97 & 0,062 & 0,970 & 6,014 & \\
\hline $\mathrm{R}$ & 96 & 0,043 & 0,666 & 4,128 & \\
\hline
\end{tabular}

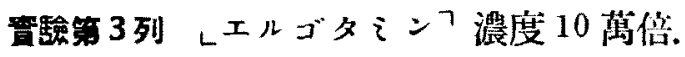

\section{第 23 表}

昭和 5 年 7 月 23 日 液温 $21^{\circ} \mathrm{C}$

\begin{tabular}{|c|c|c|c|c|c|}
\hline 灌流液 & $\begin{array}{l}20 \text { 分間 } \\
\text { 流出量 } \\
(\mathrm{ccm}) \\
\end{array}$ & $\begin{array}{c}\text { lecm } \\
\text { 中榶量 } \\
(\mathrm{mg}) \\
\end{array}$ & $\begin{array}{c}\text { 所 } 1 g \\
\text { 出榶量 } \\
\text { (mg) }\end{array}$ & $\mid \begin{array}{c}\text { 總出䅯量 } \\
(\mathrm{mg})\end{array}$ & $\begin{array}{c}\text { 䀒重复 } \\
(\mathrm{g}) \\
\end{array}$ \\
\hline $\mathrm{R}$ & 98 & 0,046 & 0,375 & 4,508 & 12 \\
\hline$R+E$ & 98 & 0,057 & 0,465 & 5,586 & \\
\hline$R+E$ & 96 & 0,059 & 0,472 & 5,664 & \\
\hline $\mathrm{R}$ & 95 & 0,050 & 0,395 & 4,750 & \\
\hline
\end{tabular}

\section{第 24 表}

昭和 5 年 7 月 31 日 液温 $20^{\circ} \mathrm{C}$

\begin{tabular}{|c|c|c|c|c|c|}
\hline 灌流液 & 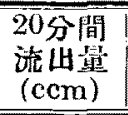 & $\begin{array}{c}1 \mathrm{ccm} \\
\text { 中阽量 } \\
(\mathrm{mg})\end{array}$ & $\begin{array}{c}\text { 䏦 } 1 \mathrm{~g} \\
\text { 出榶量 } \\
\text { (mg) }\end{array}$ & 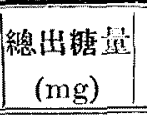 & $\begin{array}{c}\text { 䀒重量 } \\
(\mathrm{g})\end{array}$ \\
\hline $\mathrm{R}$ & 109 & 0,020 & 0,290 & 2,180 & 7,5 \\
\hline$R+E$ & 106 & 0,027 & 0,381 & 2,862 & \\
\hline $\mathrm{R}+\mathrm{E}$ & 106 & 0,025 & 0,353 & 2,650 & \\
\hline $\mathbf{R}$ & 108 & 0,024 & 0,345 & 2,592 & \\
\hline
\end{tabular}

寅驗第 4 列 レエルゴタミンフ濃度 20 萬倍.

\section{第 25 表}

昭和 5 年 7 月 19 日 液温 $20^{\circ} \mathrm{C}$

\begin{tabular}{|c|c|c|c|c|c|}
\hline 濩湤液 & 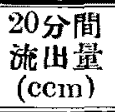 & $\begin{array}{c}1 \mathrm{ccm} \\
\text { 中糖量 } \\
\text { (mg) }\end{array}$ & $\begin{array}{c}\text { 奣 } 1 \mathrm{~g} \\
\text { 出精量 } \\
(\mathrm{mg})\end{array}$ & $\mid \begin{array}{c}\text { 總山捃量 } \\
(\mathrm{mg})\end{array}$ & $\begin{array}{c}\text { 䀒重量 } \\
(\mathrm{g}) \\
\end{array}$ \\
\hline $\mathrm{R}$ & 97 & 0,061 & 0,514 & 5,917 & 11,5 \\
\hline$R+E$ & 99 & 0,066 & 0,568 & 6,534 & \\
\hline $\mathbf{R}+\mathbf{E}$ & 98 & 0,059 & 0,502 & 5,782 & \\
\hline $\mathrm{R}$ & 99 & 0,061 & 0,525 & 6,039 & \\
\hline
\end{tabular}

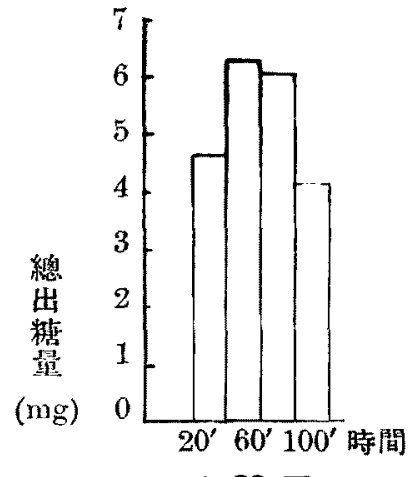

第 22 圖

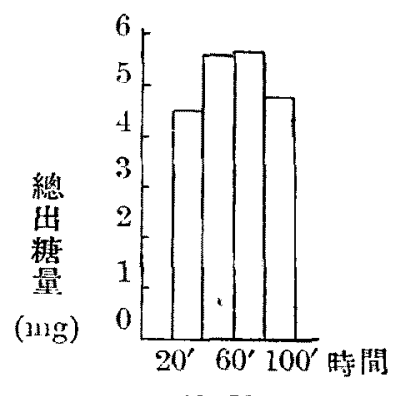

第 23 圖
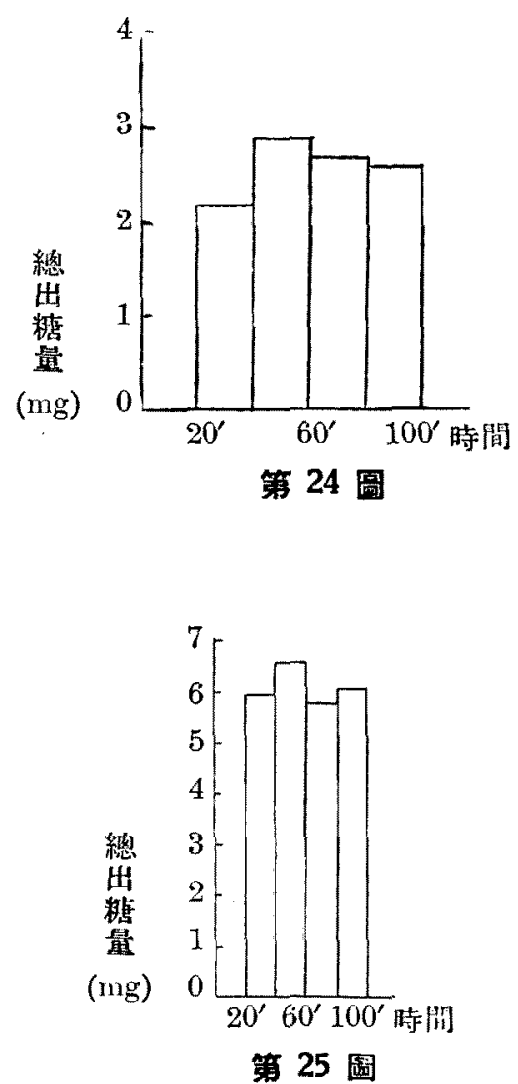
淢 25 表

昭和 5 年 7 月 30 日 液温 $20^{\circ} \mathrm{C}$

\begin{tabular}{|c|c|c|c|c|c|}
\hline 熦流液 & $\begin{array}{l}20 \text { 分閏 } \\
\text { 流出量 } \\
(\mathrm{ccm})\end{array}$ & $\begin{array}{c}1 \mathrm{ccm} \\
\text { 中糖量 } \\
(\mathrm{mg})\end{array}$ & 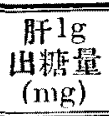 & $\begin{array}{c}\text { 總出精量 } \\
(\mathrm{mg})\end{array}$ & $\begin{array}{c}\text { 肔重量 } \\
(\mathrm{mg})\end{array}$ \\
\hline $\mathrm{R}$ & 93 & 0,041 & 0,586 & 3,813 & 6,5 \\
\hline$R+E$ & 90 & 0,036 & 0,498 & 3,240 & \\
\hline$R+E$ & 91 & 0,038 & 0,532 & 3,458 & \\
\hline R & 92 & 0,039 & 0,552 & 3,588 & \\
\hline
\end{tabular}

第驗第 5 列 レエルゴタミンフ 50 第倍

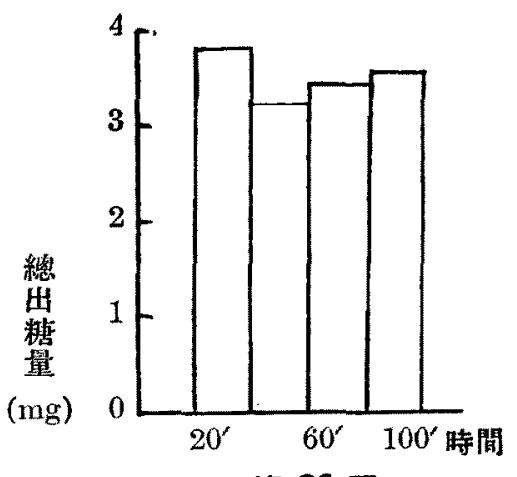

第 26 圆

\section{萧 27 震}

昭和 5 年 7 月 28 日 液温 $20^{\circ} \mathrm{C}$

\begin{tabular}{|c|c|c|c|c|c|}
\hline 灌流液 & $\begin{array}{l}20 \text { 分閔 } \\
\text { 流出量 } \\
(\mathrm{ccm}) \\
\end{array}$ & $\begin{array}{l}\text { 1 cern } \\
\text { 中榶量 } \\
\text { (mg) }\end{array}$ & 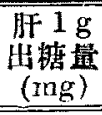 & $\begin{array}{c}\text { 總出糖量 } \\
(\mathrm{mg})\end{array}$ & $\begin{array}{c}\text { 旰重㖏 } \\
(\mathrm{g}) \\
\end{array}$ \\
\hline $\mathbf{R}$ & 86 & 0,024 & 0,589 & 2,064 & 3,5 \\
\hline $\mathbf{R}+\mathbf{E}$ & 85 & 0,021 & 0,510 & 1,785 & \\
\hline $\mathrm{R}+\mathrm{E}$ & 86 & 0,023 & $.0,565$ & 1,978 & \\
\hline $\mathrm{R}$ & 84 & 0,023 & 0,552 & 1,932 & \\
\hline
\end{tabular}

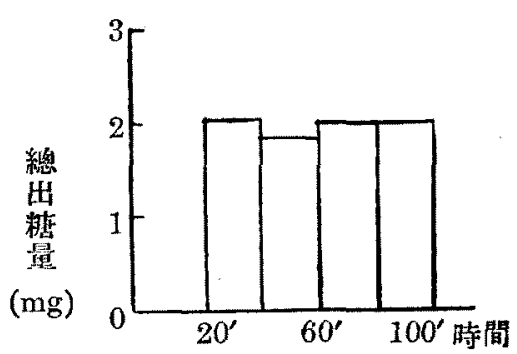

第 27

\section{考察}

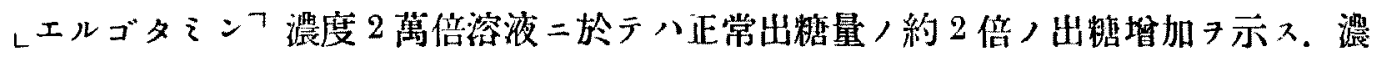
度 5 萬倍二於テハ約 1,4 倍，10萬倍二於テハ僅カ二堆加スレドモ 20 萬倍二拎テハ成績稍 了一定 $尹$ 缺キ, 時二正常二比シ僅カ二增加スレド多數例二於テ八正常ヨリ僅カ二低下ス. 50 萬倍ニ於テハ殆ンド作用セザルモ，如シ. 要スルニレエルゴタミンフ，作用ハ大量二

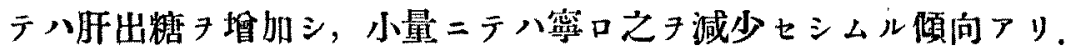

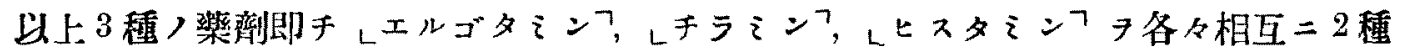

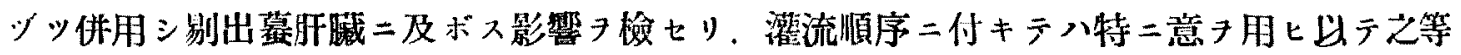

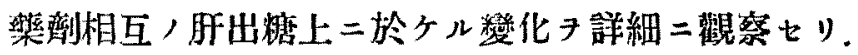

\section{4. ᄂヒスタ ミンフ 加 レチラミンフ}

紫驗第 1 列 レヒスタ 噍流液，順序心次表二示ス如シ。 
第 28 表

昭和 5 年 7 月 29 日 液温 $20^{\circ} \mathrm{C}$

\begin{tabular}{|c|c|c|c|c|c|}
\hline 灌流渡 & $\begin{array}{l}20 \text { 分閻 } \\
\text { 湤讪 } \\
\text { (ccm) }\end{array}$ & $\begin{array}{c}1 \mathrm{ccm} \\
\text { 中掼 } \\
\text { (mg) } \\
\end{array}$ & $\begin{array}{c}\text { 奣 } 1 \mathrm{~g} \\
\text { 出榶量 } \\
(\mathrm{mg})\end{array}$ & $\mid \begin{array}{c}\text { 總 }(\mathrm{H} \text { 䅯量 } \\
(\mathrm{mg})\end{array}$ & $\begin{array}{c}\text { 肝重量 } \\
(\mathrm{g})\end{array}$ \\
\hline $\mathbf{R}$ & 92 & 0,024 & 0,631 & 2,208 & 3,5 \\
\hline $\mathrm{R}+\mathrm{H}$ & 90 & 0,022 & 0,563 & 1,980 & \\
\hline $\mathbf{R}+\mathbf{H}+\mathbf{T}$ & 92 & 0,044 & 1,157 & 4,048 & \\
\hline $\mathrm{R}+\mathrm{H}$ & 91 & 0,019 & 0,494 & 1,729 & \\
\hline $\mathbf{R}$ & 93 & 0,018 & 0,478 & 1,674 & \\
\hline
\end{tabular}

第 29 表

昭和 5 年 7 月 24 日 液温 $20^{\circ} \mathrm{C}$

\begin{tabular}{|c|c|c|c|c|c|}
\hline 灌流液 & 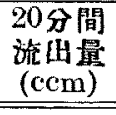 & $\begin{array}{c}1 \mathrm{ccm} \\
\text { 中糖㫫 } \\
(\mathrm{mg})\end{array}$ & $\begin{array}{c}\text { 奣 } 1 \mathrm{~g} \\
\text { 保糖量 } \\
(\mathrm{mg}) \\
\end{array}$ & $\begin{array}{c}\text { 總出糖量 } \\
(\mathrm{mg})\end{array}$ & $\begin{array}{c}\begin{array}{c}\text { 旰重量 } \\
(\mathrm{g})\end{array} \\
\end{array}$ \\
\hline $\mathbf{R}$ & 110 & 0,034 & 0,485 & 3,740 & 7,7 \\
\hline $\mathrm{R}+\mathrm{H}$ & 109 & 0,034 & 0,581 & 3,706 & \\
\hline $\mathbf{R}+\dot{\mathbf{H}}+\mathbf{T}$ & 107 & 0,060 & 0,834 & 6,420 & \\
\hline$R+T$ & 109 & 0,024 & 0,340 & 2,616 & \\
\hline $\mathbf{R}$ & 109 & 0,024 & 0,340 & 2,616 & \\
\hline
\end{tabular}

第 30 表

昭和 5 年 7 月 27 日 液温 $21^{\circ} \mathrm{C}$

\begin{tabular}{|c|c|c|c|c|c|}
\hline 灌施液 & $\begin{array}{l}20 \text { 分間 } \\
\text { 流出量 } \\
(\mathrm{cm}) \\
\end{array}$ & $\begin{array}{c}1 \mathrm{cmm} \\
\text { 中糖量 } \\
\text { (mg) } \\
\end{array}$ & 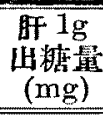 & \begin{tabular}{|c} 
總出糖器 \\
$(\mathrm{mg})$
\end{tabular} & $\begin{array}{c}\text { 肝重星 } \\
(\mathrm{g})\end{array}$ \\
\hline $\mathrm{R}$ & 95 & 0,022 & 0,596 & 2,090 & 3,5 \\
\hline $\mathbf{R}+\mathbf{T}$ & 94 & 0,029 & 0,779 & 2,726 & \\
\hline $\mathrm{R}+\mathrm{T}+\mathrm{H}$ & 95 & 0,047 & 1,276 & 4,465 & \\
\hline $\mathrm{R}+\mathrm{T}$ & 95 & 0,033 & 0,896 & 3,135 & \\
\hline $\mathrm{R}$ & 92 & 0,027 & 0,709 & 2,484 & \\
\hline
\end{tabular}

第 31 表

昭和 5 年. 7 月 25 日 液温 $20^{\circ} \mathrm{C}$

\begin{tabular}{|c|c|c|c|c|c|}
\hline 灌旅液 & $\begin{array}{l}20 \text { 分間 } \\
\text { 楛出量 } \\
(\mathrm{ccm}) \\
\end{array}$ & $\begin{array}{l}1 \mathrm{ccm} \\
\text { 中䌅量 } \\
(\mathrm{mg}) \\
\end{array}$ & 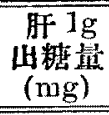 & $\begin{array}{c}\text { 䅰出䅯量 } \\
(\mathrm{mg})\end{array}$ & $\begin{array}{c}\text { 䀒重偪 } \\
(\mathrm{g}) \\
\end{array}$ \\
\hline $\mathrm{R}$ & 94 & 0,020 & 0,671 & 1,880 & 2,8 \\
\hline $\mathbf{R}+\mathbf{T}$ & 92 & 0,031 & 1,019 & 2,852 & \\
\hline $\mathrm{R}+\mathrm{T}+\mathrm{H}$ & 94 & 0,045 & 1,511 & 4,230 & \\
\hline $\mathrm{B}+\mathrm{T}$ & 95 & 0,034 & 1,153 & 3,230 & \\
\hline $\mathrm{R}$ & 95 & 0,018 & 0,611 & 1,710 & \\
\hline
\end{tabular}

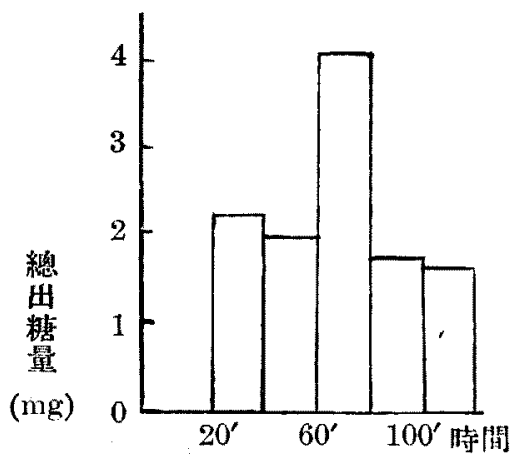

第 28 圆
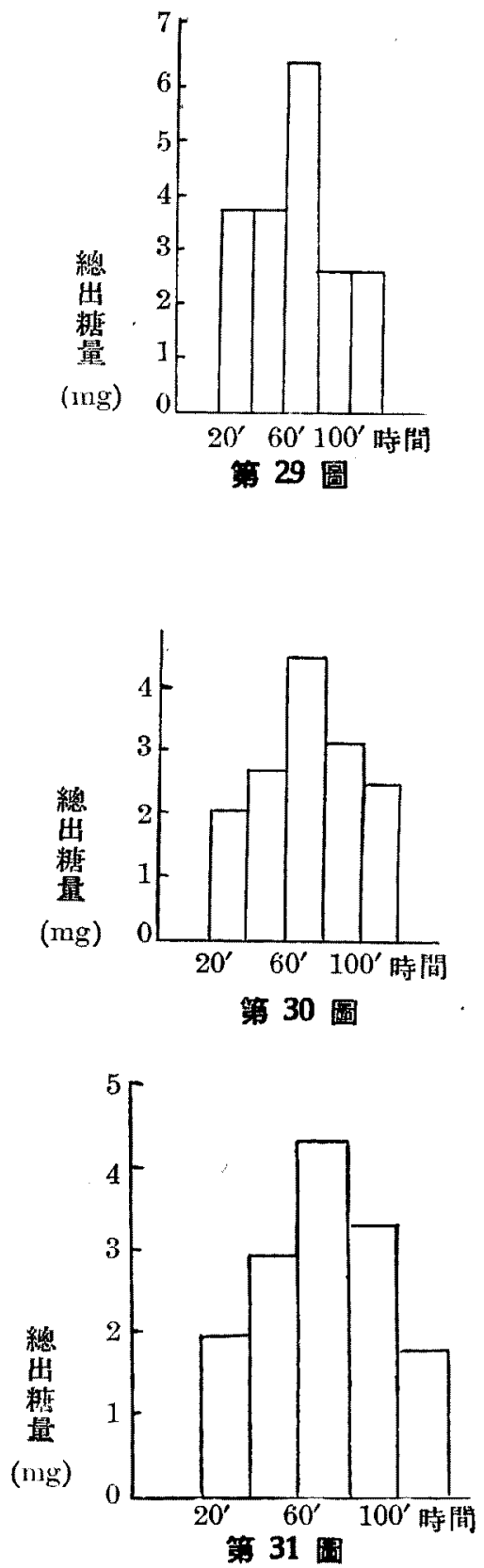


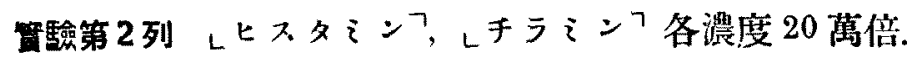

第 32 表

昭和 5 年 7 月 26 日 湤温 $21 \mathrm{C}$

\begin{tabular}{|c|c|c|c|c|c|}
\hline 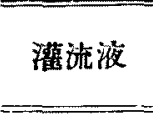 & $\begin{array}{l}20 \text { 分間 } \\
\text { 流出量 } \\
(\mathrm{ccm})\end{array}$ & $\begin{array}{c}1 \mathrm{ccm} \\
\text { 中糖量 } \\
(\mathrm{mg}) \\
\end{array}$ & $\begin{array}{c}\text { ff } 1 \mathrm{~g} \\
\text { 出掂最 } \\
\text { (ng) }\end{array}$ & 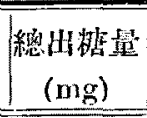 & $\begin{array}{c}\text { 肝重量 } \\
(\mathrm{g}) \\
\end{array}$ \\
\hline $\mathbf{F}$ & 104 & 0,023 & 0,435 & 2,392 & 5,5 \\
\hline $\mathrm{R}+\mathrm{H}$ & 103 & 0,022 & 0,412 & 2,266 & \\
\hline $\mathrm{R}+\mathrm{H}+\mathrm{T}$ & 105 & 0,040 & 0,764 & 4,200 & \\
\hline $\mathrm{R}+\mathrm{H}$ & 104 & 0,031 & 0,586 & 3,224 & \\
\hline $\mathbf{R}$ & 106 & 0,022 & 0,424 & 2,332 & \\
\hline
\end{tabular}

第 33 表

炤和 5 年 8 月 2 日 液温 $20^{\circ} \mathrm{C}$

\begin{tabular}{|c|c|c|c|c|c|}
\hline 灌流液 & $\begin{array}{l}20 \text { 分間 } \\
\text { 施出量 } \\
\text { (ccm) }\end{array}$ & $\begin{array}{l}\operatorname{lecm} \\
\text { 中榶量 } \\
\text { (1ng) }\end{array}$ & $\begin{array}{c}\text { 晘 } 1 \mathrm{~g} \\
\text { 出榶量 } \\
\text { (mg) }\end{array}$ & $\begin{array}{c}\text { 總岾糖量 } \\
(\mathbf{n}) \mathrm{g})\end{array}$ & $\begin{array}{c}\text { 肝重量 } \\
(\mathrm{g})\end{array}$ \\
\hline $\mathrm{R}$ & 99 & 0,047 & 0,490 & 4,653 & 9,5 \\
\hline $\mathrm{R}+\mathrm{H}$ & 97 & 0,047 & 0,479 & 4,559 & \\
\hline $\mathrm{R}+\mathrm{T}+\mathrm{H}$ & 98 & 0,072 & 0,743 & 7,056 & \\
\hline $\mathrm{R}+\mathrm{H}$ & 98 & 0,038 & 0,392 & 3,724 & \\
\hline $\mathrm{R}$ & 99 & 0,041 & 0,427 & 4,059 & \\
\hline
\end{tabular}

第 34 表

昭和 5 年 8 月 3 日 液温 $20^{\circ} \mathrm{C}$

\begin{tabular}{|c|c|c|c|c|c|}
\hline 灌流液 & $\begin{array}{l}20 \text { 分間 } \\
\text { 流出最 } \\
(\mathrm{ccm}) \\
\end{array}$ & $\begin{array}{l}\mathrm{ccm} \\
\text { 中粘量 } \\
\text { (mg) }\end{array}$ & $\begin{array}{l}\text { 晘 } 1 \mathrm{~g} \\
\text { 出惦量 } \\
\text { (mg) }\end{array}$ & $\begin{array}{c}\text { 總出榶宣 } \\
(\mathrm{mg})\end{array}$ & 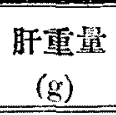 \\
\hline $\mathrm{R}$ & 103 & 0,027 & 0,677 & 2,781 & 4,5 \\
\hline $\mathbf{R}+\mathbf{T}$ & 101 & 0,036 & 0,801 & 3,636 & \\
\hline $\mathrm{R}+\mathrm{T}+\mathrm{H}$ & 101 & 0,058 & 1,302 & 5,858 & \\
\hline$R+T$ & 103 & 0,029 & 0,664 & 2,987 & \\
\hline $\mathbf{R}$ & 103 & 0,020 & 0,458 & 2,060 & \\
\hline
\end{tabular}

第 35 秦

昭和 5 年 8 月 10 日 液温 $21^{\circ} \mathrm{C}$

\begin{tabular}{|c|c|c|c|c|c|}
\hline 灌㳊液 & $\begin{array}{l}20 \text { 分間 } \\
\text { 流出量 } \\
(\mathrm{ccm})\end{array}$ & $\begin{array}{l}1 \mathrm{ccm} \\
\text { 中榶量 } \\
\text { (ccm) }\end{array}$ & $\begin{array}{c}\text { 䏦 } 1 \mathrm{~g} \\
\text { 出梅量 } \\
\text { (mg) }\end{array}$ & $\begin{array}{c}\text { 總山䊉最 } \\
(\mathrm{mg})\end{array}$ & $\begin{array}{c}\text { 肝重㖏 } \\
(\mathrm{g})\end{array}$ \\
\hline $\mathrm{R}$ & 90 & 0,036 & 0,490 & 3,240 & 6,6 \\
\hline $\mathrm{R}+\mathrm{T}$ & 92 & 0,047 & 0,655 & 4,324 & \\
\hline $\mathrm{R}+\mathrm{T}+\mathrm{H}$ & 87 & 0,077 & 1,015 & 6,699 & \\
\hline $\mathrm{R}+\mathrm{T}$ & 90 & 0,054 & 0,736 & 4,860 & \\
\hline $\mathrm{R}$ & 89 & 0,034 & 0,458 & 3,026 & \\
\hline
\end{tabular}
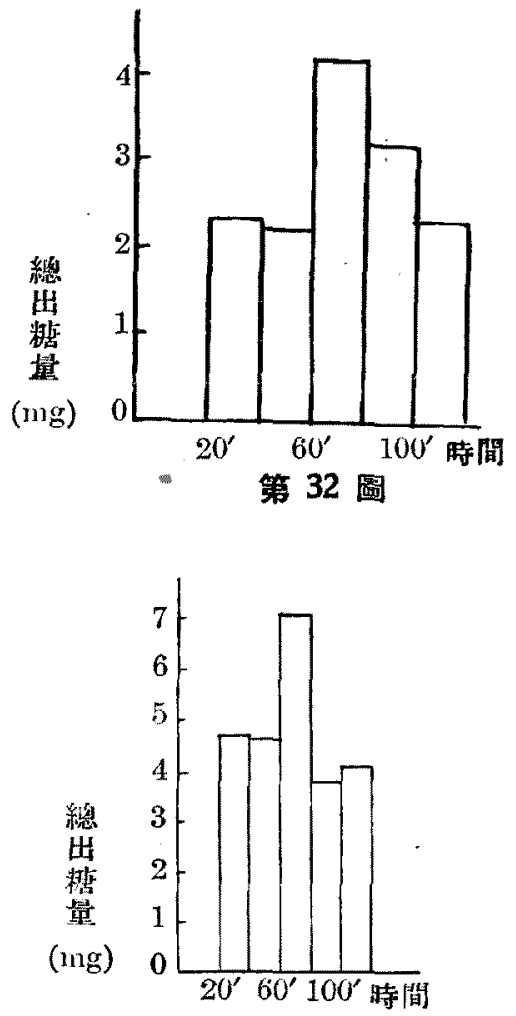

第 33 圆:

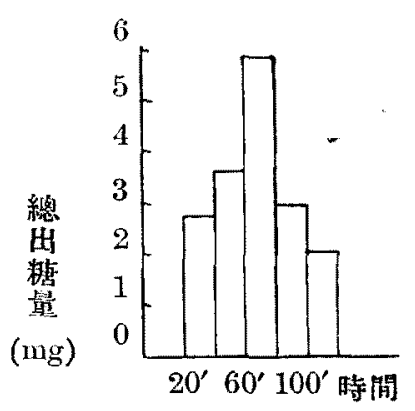

第 34 圖

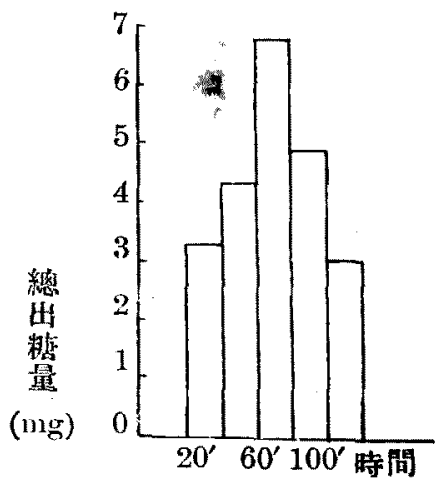

第 35 圖 


\section{考察}

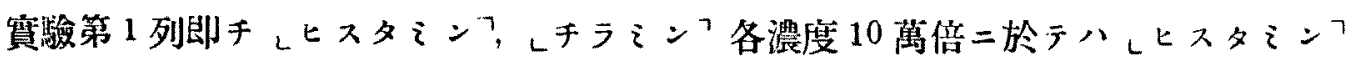

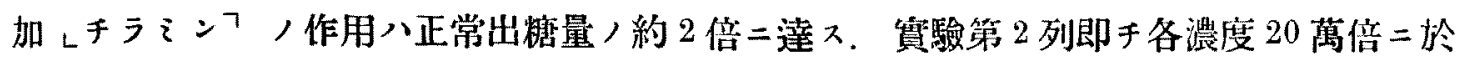

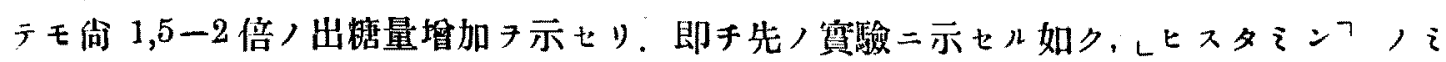

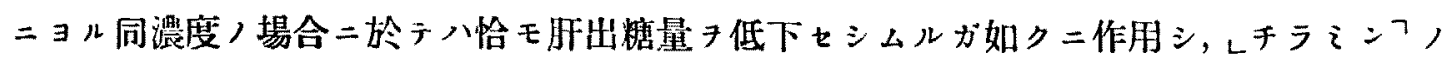
ミノ同涱度, 實驗二於テハそレ二反シ肝出船 7 僅か二助長促進シ, 對照二比シ約 1,5 倍以

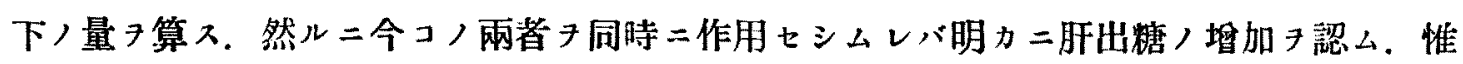
フニコノ兩䊾恋間二一定度所謂 Synergismus ナル作用存スルモノナルベシ。

\section{5. ᄂヒスタミンフ加レエルゴタミンフ}

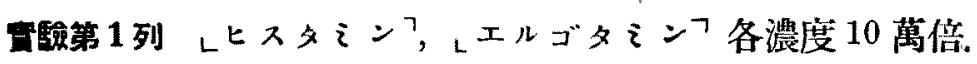

\section{第 36 表}

昭和 5 年 8 月 5 日 湤温 $20^{\circ} \mathrm{C}$

\begin{tabular}{|c|c|c|c|c|c|}
\hline 灌流液 & 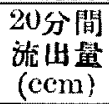 & 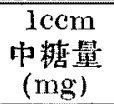 & 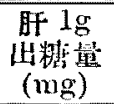 & $\mid \begin{array}{c}\text { 總出糖重 } \\
(\mathrm{mg})\end{array}$ & $\begin{array}{c}\text { 肝重墨 } \\
(\mathrm{mg})\end{array}$ \\
\hline $\mathbf{R}$ & 99 & 0,042 & 0,594 & 4,158 & 7. \\
\hline $\mathrm{R} \longmapsto \mathrm{H}$ & 99 & 0,042 & 0,594 & 4,158 & \\
\hline $\mathrm{R}+\mathrm{H}+\mathbf{E}$ & 98 & 0,044 & 0,616 & 4,312 & \\
\hline $\mathbf{R}+\mathbf{H}$ & 100 & 0,037 & 0,528 & 3,700 & \\
\hline $\mathbf{R}$ & 98 & 0,039 & 0,546 & 3,822 & \\
\hline
\end{tabular}

第 36 表

昭和 5 年 8 月 10 日 液溫 $21^{\circ} \mathrm{C}$

\begin{tabular}{|c|c|c|c|c|c|}
\hline 灌流液 & $\begin{array}{l}20 \text { 分間 } \\
\text { 流出 } \\
(\mathrm{ccm}) \\
\end{array}$ & $\begin{array}{l}1 \mathrm{ccm} \\
\text { 中溏量 } \\
\text { (mg) } \\
\end{array}$ & 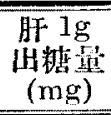 & $\begin{array}{c}\text { 總出妳量 } \\
(\mathrm{ng} g)\end{array}$ & $\begin{array}{r}\text { 肝重量 } \\
(\mathrm{mg}) \\
\end{array}$ \\
\hline$R$ & 98 & 0,045 & 0,612 & 4,410 & 7,2 \\
\hline $\mathrm{R}+\mathrm{H}$ & 98 & 0,043 & 0,585 & 4,214 & \\
\hline $\mathrm{R}+\mathrm{H}+\mathbf{E}$ & 99 & 0,045 & 0,632 & 4,455 & \\
\hline $\mathrm{R}+\mathrm{H}$ & 99 & 0,038 & 0,522 & 3,762 & \\
\hline $\mathrm{R}$ & 96 & 0,043 & 0,573 & 4,128 & \\
\hline
\end{tabular}

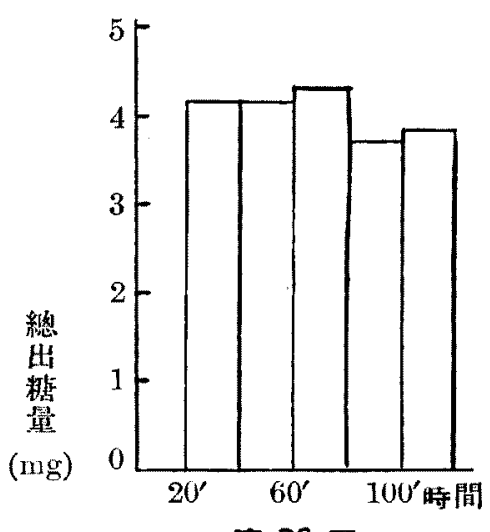

第 36 圖

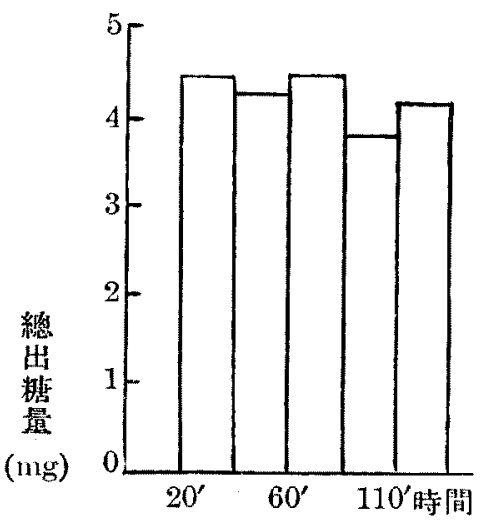

第 37 圆 
第 38 表

昭和 5 年 8 月 6 日 液温 $20^{\circ} \mathrm{C}$

\begin{tabular}{|c|c|c|c|c|c|}
\hline 灌游液 & 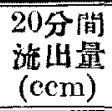 & $\begin{array}{l}1 \mathrm{ccm} \\
\text { 中梏量 } \\
\text { (mg) }\end{array}$ & 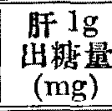 & \begin{tabular}{|c} 
總出煻䁷 \\
(mg $)$
\end{tabular} & $\begin{array}{c}\text { 肝重量 } \\
(\mathrm{g}) \\
\end{array}$ \\
\hline $\mathrm{R}$ & 88 & 0,038 & 0,514 & 3,344 & 6,5 \\
\hline $\mathrm{R}+\mathrm{E}$ & 89 & 0,049 & 0,670 & 4,361 & \\
\hline $\mathrm{R}+\mathrm{E}+\mathrm{H}$ & 86 & 0,049 & 0,648 & 4,214 & \\
\hline$R+E$ & 88 & 0,047 & 0,619 & 4,026 & \\
\hline R & 86 & 0,042 & 0,555 & 3,612 & \\
\hline
\end{tabular}

\section{第 39 表}

昭和 5 年 8 月 9 日 湤温 $20^{\circ} \mathrm{C}$

\begin{tabular}{|c|c|c|c|c|c|}
\hline 戬流液 & $\begin{array}{r}20 \text { 分閔流 } \\
(\mathrm{cccm})\end{array}$ & $\begin{array}{l}1 \mathrm{ccm} \\
\text { 中犍量 } \\
\text { (mg) }\end{array}$ & 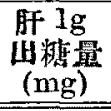 & 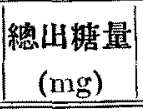 & $\begin{array}{c}\text { 汘重量 } \\
(\mathrm{g}) \\
\end{array}$ \\
\hline $\mathrm{R}$ & 73 & 0,017 & 0,443 & 1,241 & 2,8 \\
\hline $\mathrm{R}+\mathrm{E}$ & 75 & 0,022 & 0,589 & 1,650 & \\
\hline $\mathbf{R}+\mathbf{E}+\mathbf{H}$ & 75 & 0,017 & 0,455 & 1,275 & \\
\hline$R+E$ & 76 & 0,019 & 0,515 & 1,444 & \\
\hline$R$ & 74 & 0,019 & 0,502 & 1,406 & \\
\hline
\end{tabular}
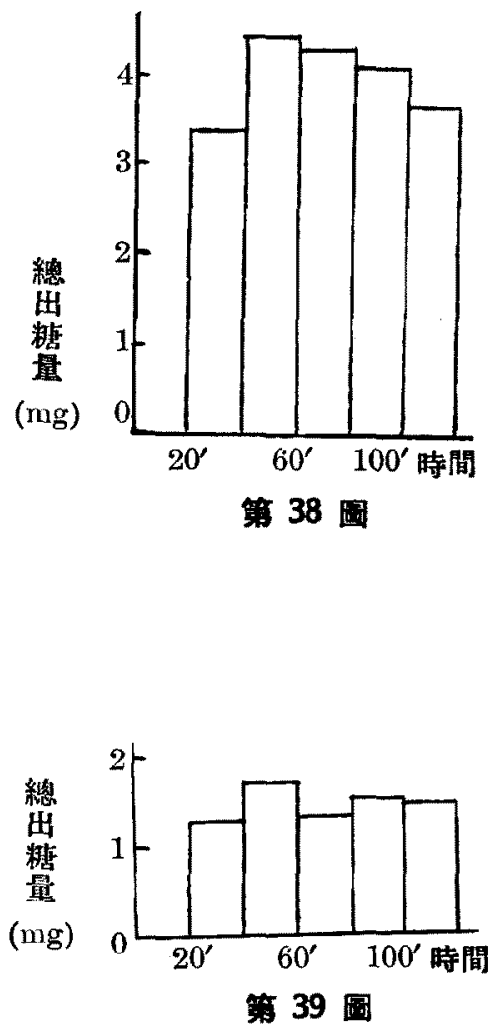

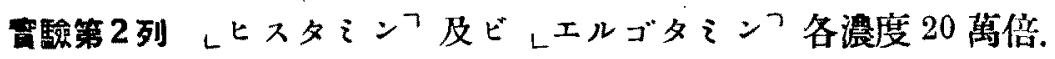

第 40 表

昭和 5 年 8 月 7 日 液温 $21^{\circ} \mathrm{C}$

\begin{tabular}{|c|c|c|c|c|c|}
\hline 灌流液 & 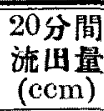 & $\begin{array}{l}1 \mathrm{ccm} \\
\text { 中糖量 } \\
(\mathrm{mg})\end{array}$ & 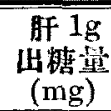 & $\begin{array}{c}\text { 綪出楼量 } \\
(\mathrm{mg})\end{array}$ & $\begin{array}{c}\text { 旰重量 } \\
(\mathrm{g})\end{array}$ \\
\hline $\mathbf{R}$ & 94 & 0,019 & 0,714 & 1,786 & 2,5 \\
\hline $\mathbf{R}+\mathbf{H}$ & 94 & 0,017 & 0,639 & 1,598 & \\
\hline $\mathrm{R}+\mathrm{H}+\mathrm{E}$ & 93 & 0,021 & 0,781 & 1,953 & \\
\hline $\mathbf{R}+\mathbf{H}$ & 95 & 0,019 & 0,722 & 1,805 & \\
\hline $\mathrm{R}$ & 94 & 0,021 & 0,789 & 1,974 & \\
\hline
\end{tabular}

第 41 表

昭和 5 年 8 月 8 日 旅温 $21 \mathrm{C}$

\begin{tabular}{|c|c|c|c|c|c|}
\hline 灌淤液 & $\begin{array}{l}20 \text { 分間 } \\
\text { 流出量 } \\
\text { (ccm) }\end{array}$ & $\begin{array}{l}1 \mathrm{ccm} \\
\text { 中䌅量 } \\
\text { (mg) }\end{array}$ & 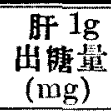 & 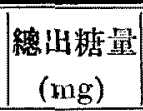 & $\begin{array}{c}\text { 肝重量 } \\
(\mathrm{g})\end{array}$ \\
\hline $\mathbf{R}$ & 95 & 0,021 & 0,870 & 1,915 & 2,2 \\
\hline $\mathrm{R}+\mathrm{H}$ & 96 & 0,016 & 0,698 & 1,536 & \\
\hline $\mathrm{R}+\mathrm{H}+\mathrm{E}$ & 95 & 0,018 & 0,772 & 1,710 & \\
\hline $\mathrm{R}+\mathrm{H}$ & 95 & 0,018 & 0,772 & 1,710 & \\
\hline $\mathrm{R}$ & 93 & 0,019 & 0,803 & 1,767 & \\
\hline
\end{tabular}
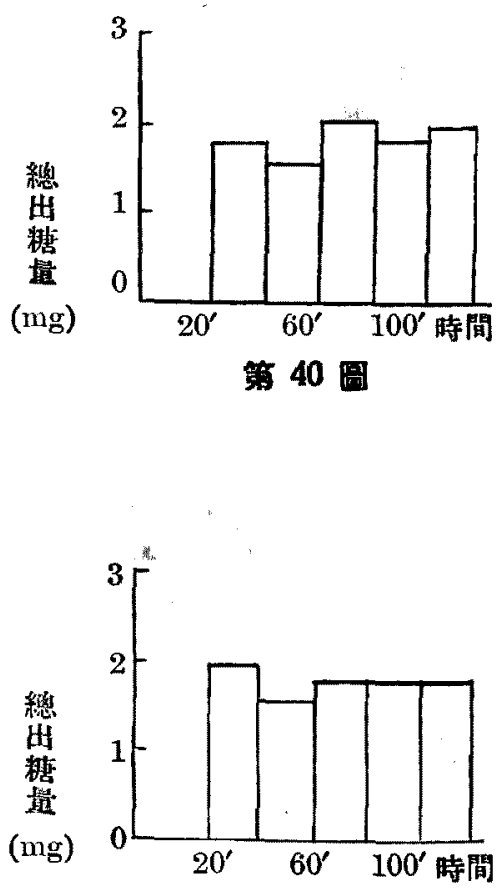

第 41 圆 
茀 42 表

昭和 5 年 8 月 11 日 波溫 $20^{\circ} \mathrm{C}$

\begin{tabular}{|c|c|c|c|c|c|}
\hline 灌流液 & $\begin{array}{l}20 \text { 分䦩 } \\
\text { 流出量 } \\
\text { (ccm) }\end{array}$ & $\begin{array}{c}1 \mathrm{ccm} \\
\text { 中榶量 } \\
(\mathrm{mg})\end{array}$ & 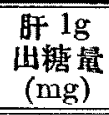 & 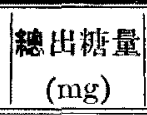 & $\begin{array}{c}\text { 旰重量 } \\
(\mathrm{g}) \\
\end{array}$ \\
\hline $\mathrm{R}$ & 95 & 0,028 & 0,831 & 2,660 & 3,2 \\
\hline $\mathbf{R}+\mathbf{E}$ & 93 & 0,028 & 0,814 & 2,604 & \\
\hline $\mathrm{R}+\mathrm{E}+\mathrm{H}$ & 96 & 0,030 & 0,900 & 2,880 & \\
\hline $\mathbf{R}+\mathbf{E}$ & 94 & 0,028 & 0,822 & 2,632 & \\
\hline $\mathrm{R}$ & 96 & 0,026 & 0,780 & 2,496 & \\
\hline
\end{tabular}

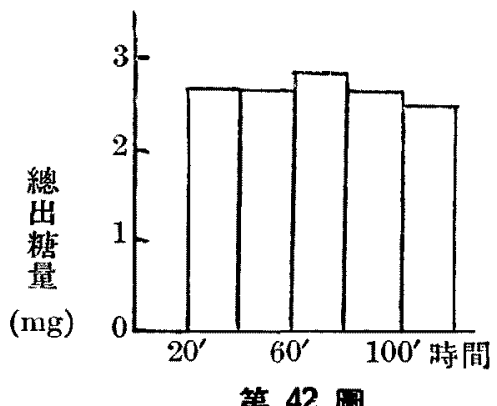

苐 43 表

昭和 5 年 8 月 20 日 液温 $21^{\circ} \mathrm{C}$

\begin{tabular}{|c|c|c|c|c|c|}
\hline 灌流液 & $\begin{array}{l}\text { 20分間 } \\
\text { 流出量 } \\
(\mathrm{ccm})\end{array}$ & $\begin{array}{c}1 \mathrm{ccm} \\
\text { 中榶軖 } \\
(\mathrm{mg})\end{array}$ & $\begin{array}{c}\text { 䛞 } 1 \mathrm{~g} \\
\text { 出榶量 } \\
(\mathrm{mg})\end{array}$ & 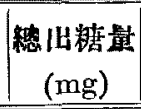 & $\begin{array}{c}\text { 肝重㖏 } \\
(\mathrm{g})\end{array}$ \\
\hline $\mathrm{R}$ & 90 & 24 & 0,720 & 2,160 & 3 \\
\hline $\mathbf{R}+\mathbf{E}$ & 89 & 22 & 0,652 & 1,958 & \\
\hline $\mathrm{R}+\mathrm{E}+\mathrm{H}$ & 91 & 25 & 0,758 & 2,275 & \\
\hline$R+E$ & 90 & 24 & 0,720 & 2,160 & \\
\hline $\mathbf{R}$ & 91 & 24 & 0,728 & 2,184 & \\
\hline
\end{tabular}

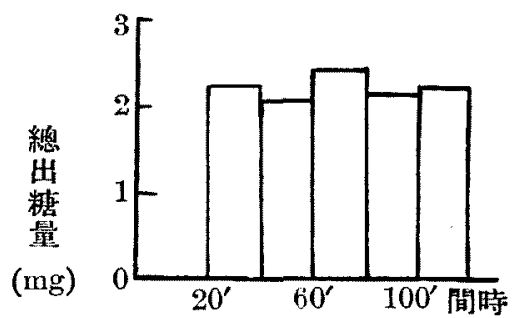

第 43 圆

\section{考察}

本實噞列チ見ルニレヒスタミンフ加レエルゴタミンフ，作用ハ10萬倍及ビ 20 萬倍，

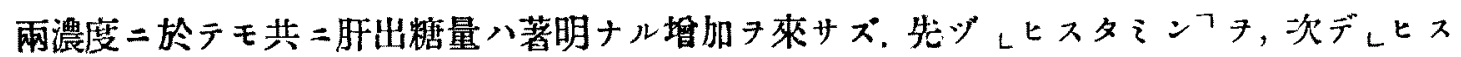

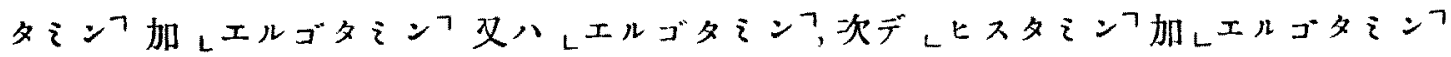
ヨ作用セシメタル場合モ共二レヒスタミンフ加レエルゴタミンフハレヒスタミンフ或ハレエ

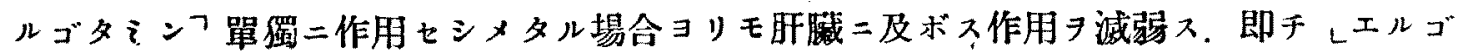

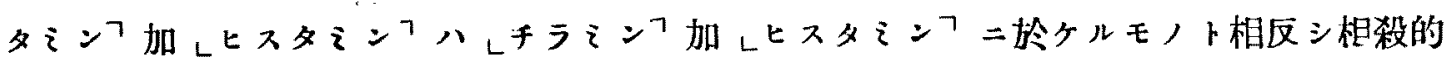
二作用ス。 サレバ其成續又 $K . S$ piro u. Basel 氏，記載二能ク合致ス.

\section{6. レチラミンフ 加 ᄂエルゴタミンフ}

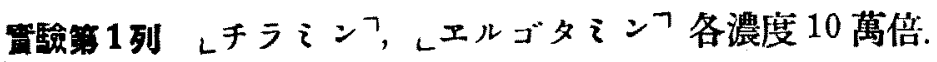


第 44 表

昭利 5 年 8 月 21 日 液温 $21^{\circ} \mathrm{C}$

\begin{tabular}{|c|c|c|c|c|c|}
\hline 灌涐液 & 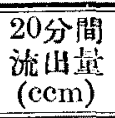 & 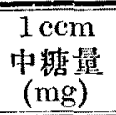 & $\begin{array}{l}\text { 橗 } 18 \\
\text { 出枯量 } \\
(\mathrm{mg})\end{array}$ & 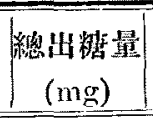 & $\begin{array}{c}\text { 胉重量 } \\
(\mathrm{g})\end{array}$ \\
\hline $\mathrm{R}$ & 96 & 0,028 & 0,384 & 2,688 & 7 \\
\hline $\mathrm{R}+\mathrm{T}$ & 98 & 0,042 & 0,588 & 4,116 & \\
\hline $\mathbf{R}+\mathbf{E}+\mathbf{T}$ & 97 & 0,084 & 1,164 & 8,148 & \\
\hline$R+T$ & 97 & 0,067 & 0,928 & 6,499 & \\
\hline $\mathrm{R}$ & 98 & 0,040 & 0,560 & 3,920 & \\
\hline
\end{tabular}

第 45 表

昭和 5 年 8 月 12 日 液温 $20^{\circ} \mathrm{C}$

\begin{tabular}{|c|c|c|c|c|c|}
\hline 灌流液 & $\begin{array}{l}20 \text { 分間 } \\
\text { 流组量 } \\
(\mathrm{ccm})\end{array}$ & $\begin{array}{c}1 c c m \\
\text { 中糖輩 } \\
(\mathrm{mg}) \\
\end{array}$ & 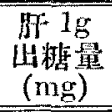 & $\begin{array}{c}\text { 總出搪星 } \\
(\mathrm{mg})\end{array}$ & $\begin{array}{c}\text { 旰重量 } \\
(\mathrm{g})\end{array}$ \\
\hline $\mathrm{R}$ & 97 & 0,026 & 0,360 & 2,522 & 7 \\
\hline $\mathrm{R}+\mathrm{T}$ & 99 & 0,036 & 0,507 & 3,554 & \\
\hline $\mathbf{R}+\mathbf{T}+\mathbf{E}$ & 98 & 0,074 & 1,036 & 7,252 & \\
\hline $\mathrm{R}+\mathrm{T}$ & 97 & 0,047 & 0,651 & 4,559 & \\
\hline $\mathrm{R}$ & 98 & 0,032 & 0,448 & 8,136 & \\
\hline
\end{tabular}

第 46 表

昭和 5 年8月 19 日 液温 $20^{\circ} \mathrm{C}$

\begin{tabular}{|c|c|c|c|c|c|}
\hline 整流液 & 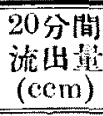 & $\begin{array}{l}1 \mathrm{ccm} \\
\text { 中牧量 } \\
\text { (mg) } \\
\end{array}$ & 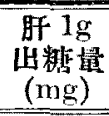 & $\begin{array}{c}\text { (mg) } \\
\end{array}$ & $\begin{array}{c}\text { 肝重量 } \\
(\mathrm{g}) \\
\end{array}$ \\
\hline $\mathrm{R}$ & 98 & 0,022 & 0,359 & 2,156 & 6 \\
\hline$R+E$ & 98 & 0,028 & 0,453 & 2,744 & \\
\hline $\mathrm{R}+\mathrm{E}+\mathrm{T}$ & 96 & 0,067 & 1,089 & 6,532 & \\
\hline $\mathbf{R}+\mathbf{E}$ & 96 & 0,053 & 0,848 & 5,088 & \\
\hline $\mathbf{R}$ & 97 & 0,026 & 0,420 & 2,522 & \\
\hline
\end{tabular}

第 47 褧

昭和54年8月 13 日 波温 $21^{\circ} \mathrm{C}$

\begin{tabular}{|c|c|c|c|c|c|}
\hline 灌流液 & $\begin{array}{l}20 \text { 分間 } \\
\text { 流出量 } \\
(\mathrm{ccm})\end{array}$ & $\begin{array}{c}\text { lcem } \\
\text { 中糖量 } \\
\text { (mg) }\end{array}$ & $\begin{array}{c}\text { 仠 } 1 \mathrm{~g} \\
\text { 出梏量 } \\
\text { (mg) }\end{array}$ & $\left|\begin{array}{c}\text { 總出糖量 } \\
\text { (mg) }\end{array}\right|$ & $\begin{array}{c}\text { 肝重量 } \\
(\mathrm{g})\end{array}$ \\
\hline $\mathrm{R}$ & 104 & 0,021 & 0,624 & 2,184 & 3,5 \\
\hline$R+E$ & 104 & 0,026 & 0,723 & 2,704 & \\
\hline $\mathbf{R}+\mathrm{E}+\mathbf{T}$ & 104 & 0,061 & 1,812 & 6,344 & \\
\hline$R+E$ & 104 & 0,021 & 0,630 & 2,205 & \\
\hline $\mathbf{R}$ & 105 & 0,019 & 0,570 & 1,995 & \\
\hline
\end{tabular}

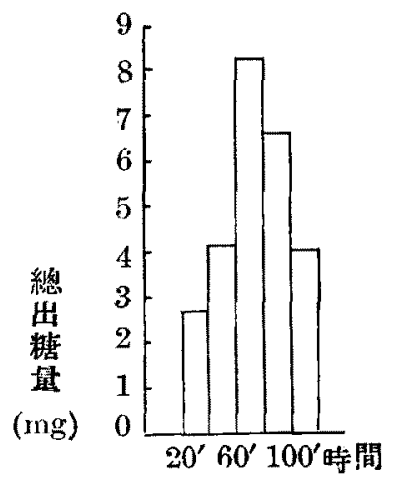

策 44 圆
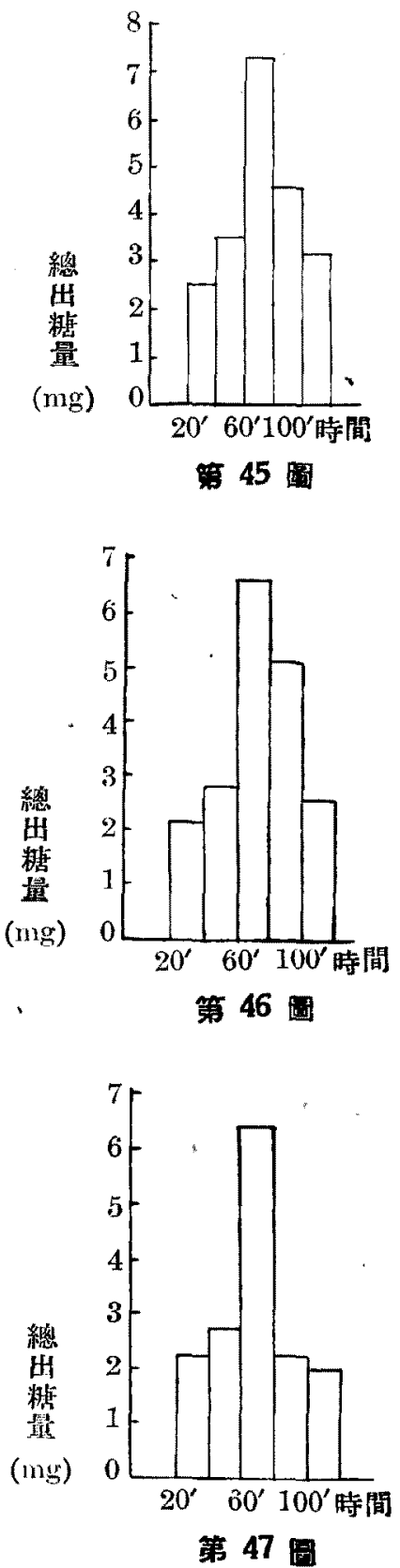


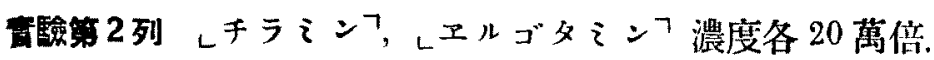

第 48 表

昭和 5 年 8 月 18 日 液温 $20^{\circ} \mathrm{C}$

\begin{tabular}{|c|c|c|c|c|c|}
\hline 灌流湤 & $\begin{array}{l}20 \text { 分間 } \\
\text { 流出量 } \\
(\mathrm{ccm}) \\
\end{array}$ & $\begin{array}{c}\text { lecm } \\
\text { 中䌅量 } \\
\text { (mg) }\end{array}$ & $\begin{array}{c}\text { 䚽 } 1 g \\
\text { 出精量: } \\
\text { (mg) }\end{array}$ & $\begin{array}{c}\text { 總但期量 } \\
(\mathrm{mg})\end{array}$ & $\begin{array}{c}\text { 肝重量 } \\
(\mathrm{mg}) \\
\end{array}$ \\
\hline $\mathrm{R}$ & 93 & 0,022 & 0,584 & 2,046 & 3,5 \\
\hline$R+T$ & 94 & 0,030 & 0,805 & 2,820 & \\
\hline $\mathrm{R}+\mathrm{T}+\mathrm{E}$ & 95 & 0,060 & 1,628 & 5,700 & \\
\hline$R+T$ & 94 & 0,043 & 1,155 & 4,042 & \\
\hline $\mathrm{R}$ & 92 & 0,024 & 0,631 & 2,208 & \\
\hline
\end{tabular}

第 49 表

昭和 5 年 8 月 15 日 党温 $20^{\circ} \mathrm{C}$

\begin{tabular}{|c|c|c|c|c|c|}
\hline 灌流液 & $\begin{array}{l}20 \text { 分間 } \\
\text { 流出量 } \\
(\mathrm{ccm})\end{array}$ & $\begin{array}{l}\text { Iccm } \\
\text { 中糖㻎 } \\
\text { (mg) } \\
\end{array}$ & $\begin{array}{c}\text { 䀒 } 1 \mathrm{~g} \\
\text { 出糖魯 } \\
(\mathrm{mg}) \\
\end{array}$ & $\mid \begin{array}{c}\text { 總山䅯量 } \\
(\mathrm{mg})\end{array}$ & $\begin{array}{c}\text { 胉重量 } \\
(\mathrm{g}) \\
\end{array}$ \\
\hline $\mathbf{R}$ & 106 & 0,018 & 0,477 . & 1,908 & 4 \\
\hline$R+T$ & 102 & 0,024 & 0,612 & 2,448 & \\
\hline $\mathrm{R}+\mathrm{T}+\mathrm{E}$ & 105 & 0,052 & 1,378 & 5,512 & \\
\hline$R+T$ & 104 & 0,027 & 0,702 & 2,808 & \\
\hline $\mathbf{R}$ & 102 & 0,018 & 0,459 & 1,836 & \\
\hline
\end{tabular}

第 50 表

昭和 5 年 8 月 14 日 液温 $21^{\circ} \mathrm{C}$

\begin{tabular}{|c|c|c|c|c|c|}
\hline 灌流液 & $\begin{array}{l}20 \text { 分間 } \\
\text { 流渚 } \\
\text { (ccm) }\end{array}$ & $\begin{array}{c}1 \mathrm{ccm} \\
\text { 中糖量 } \\
(\mathrm{mg})\end{array}$ & 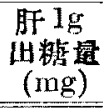 & $\mid \begin{array}{c}\text { 總出糖量 } \\
(\mathrm{mg})\end{array}$ & $\begin{array}{c}\text { 肝重量 } \\
(g)\end{array}$ \\
\hline $\mathrm{R}$ & 102 & 0,021 & 0,428 & 2,142 & 5 \\
\hline $\mathbf{R}+\mathbf{T}$ & 103 & 0,019 & 0,391 & 1,957 & \\
\hline $\mathbf{R}+\mathbf{T}+\mathbf{E}$ & 103 & 0,052 & 1,071 & 5,356 & \\
\hline $\mathbf{R}+\mathbf{T}$ & 102 & 0,029 & 0,591 & 2,958 & \\
\hline $\mathrm{R}$ & 103 & 0,027 & 0,556 & 2,781 & \\
\hline
\end{tabular}

第 51 表

昭和 5 年 8 月 17 日 液温 $20^{\circ} \mathrm{C}$

\begin{tabular}{|c|c|c|c|c|c|}
\hline 灌流洨 & $\begin{array}{l}20 \text { 分間 } \\
\text { 流诂量 } \\
(\mathrm{ccm})\end{array}$ & $\begin{array}{l}1 \mathrm{ccm} \\
\text { 中糖量 } \\
(\mathrm{mg})\end{array}$ & 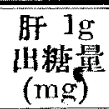 & $\left|\begin{array}{c}\text { 總仙糖量 } \\
(\mathrm{mg})\end{array}\right|$ & $\begin{array}{c}\text { 肝重盟 } \\
(\mathrm{g})\end{array}$ \\
\hline $\mathrm{R}$ & 98 & 0,027 & 0,343 & 2,646 & 7,7 \\
\hline$R+E$ & 98 & 0,029 & 0,369 & 2,842 & \\
\hline $\mathrm{R}+\mathbf{E}+\mathbf{T}$ & 96 & 0,067 & 0,835 & 6,432 & \\
\hline$R+E$ & 98 & 0,034 & 0,302 & 2,332 & \\
\hline$P$ & 97 & 0,029 & 0,365 & 2,813 & \\
\hline
\end{tabular}

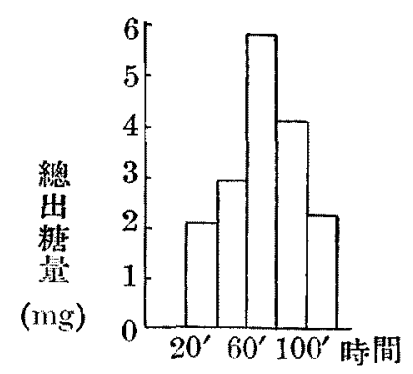

第 48 圆

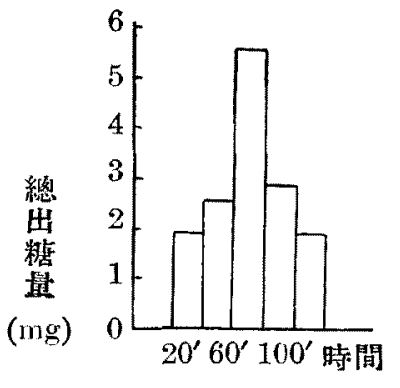

第 49 㘣
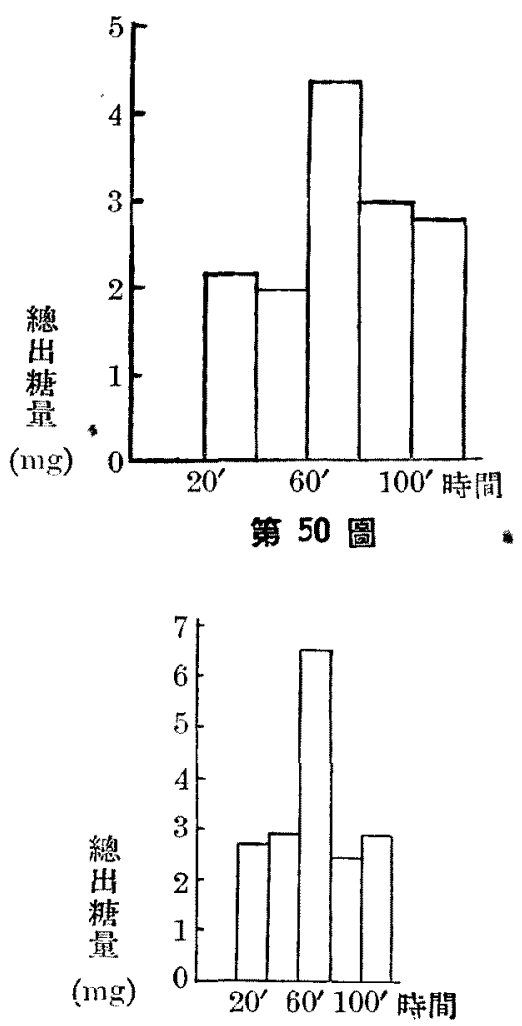

第 51 圆 


\section{考察}

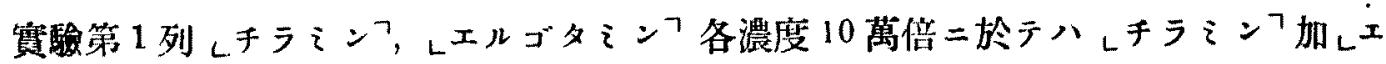
ルゴタミンフニヨル出糖量，增加ハ正常出糖量，約 3 倍キ算ス。實驗第 2 列即于濃度各 20

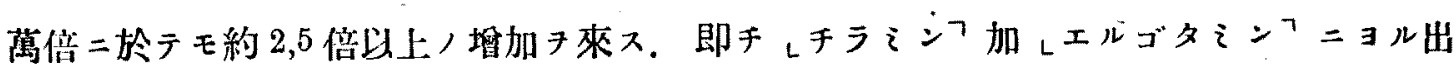
糖量ハレキラミンフ及ビレエルゴタミンフ各單獨ノ際ニ於ケル兩出糖量ノ和ヨリモ稍ヤ大 ナリ.

\section{結論}

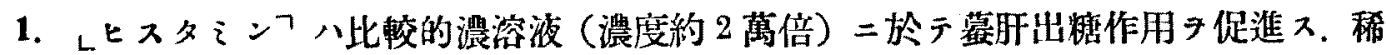
薄溶液（約 5 萬一20 䔽倍）二圪テ八寧口肝出煻作用 抑制スル傾アリ。

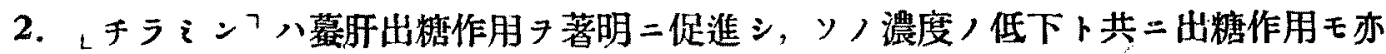
漸次减弱入。

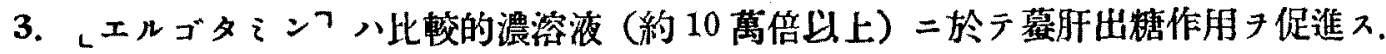
稀薄溶液二於ラ、（約 20 萬倍）ソノ作用稍ヤ一定ナラズト踓モ多ク八僅カ二肝出糖作用 ヨ低下七シム。

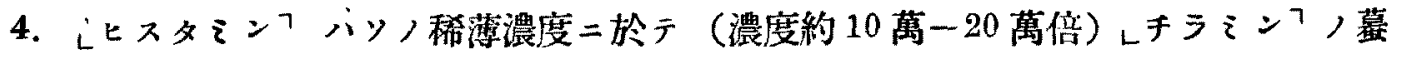
肝出糖作用 $\rightarrow$ 促進 $ᄌ$.

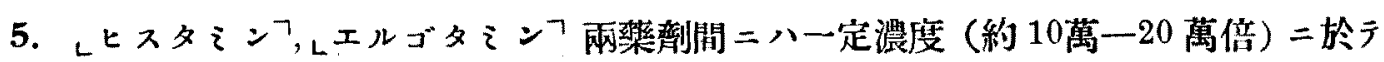
䓪肝出糖作用二對シテモ亦捛抗作用 有入。

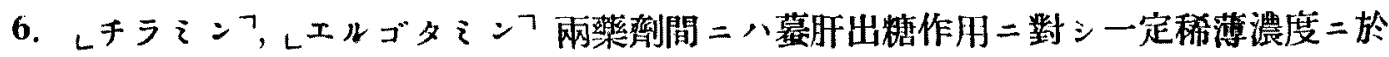
う価カ二相乘作用 (Synergismus) 存ス.

\section{引 用春}

1) Dale u. Spiro, Sehmiedebergs Archiv Bd. 95, S. 337, 1922.

2) Spiro u. Stoll, Schweizer med. Wochenschrift Nr. 23 u. 31, 1921.

3) 'I'anret, zit. nach Schmidt, Pharmaz. Chemie 5. Aufl. Bd. 2, S. 1976, 1923.

4) Barger u. Dale, ebenda.

5) M. Miculicich, Arch. f. exp. Pathol, a. Pharmakol. Bd. 69, S. 133, 1912.

6) Frölich u. Pollak, Archiv f. exp. Pathol. u. Pharmakol. Bd. 77, S. 265, 1914.

7) Hagedorn n. Jensen, Biochem. Zeitschr. Bd. 135, S. 46, 1923.

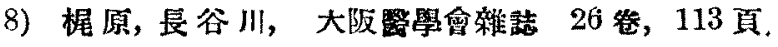

9) H. Fühner, zit. nach Feffter, Handb. d. exper. Pharmakol. Bd. 2, S. 1324, 1924

10) H. H. Dale n, P. P. Laidlaw, Journ, of physiol. Vol. 41, p. 318, 1910. 
11) H. Handousky u. E. P. Pick, Arch. f. exp. Pathol. u. Pharmakol. Bd. 71, S. 89, 1913.

12) Fröhich u. Pick, ebenda Bd. 71, S. 23, 1913.

13) Börner, ebenda Bd. 79, S. 218, 1916.

14) Schenk, ebenda Bd. 89, S. 832, 1921 u. Bd. 92, S. 34, 1922.

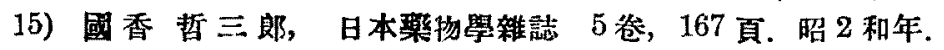

16) H. Dale u. Digon, Journ. of physiol. Vol. 39, p. 25, 1909.

17) 西脇, 大阪學學會雜誌 28 卷， 1 躆.

18) Fröhich u. Pollak, Arch. f. exp. Pathol. u. Pharmakol. Bd. 77, S. 265, 1914.

19) Burn, Journ. of physiol. Vol. 57, p. 318, 1923.

20) Lesser u. Zipf, Biochem. Zeitschr. Bd. 140, S. 612, 1923.

21) Silberslein u. Kessler, Biochem. Zeitschr. Bd. 181, S. 333, 1927.

22) Rigo u. Verzelsky, Arch. f. exp. Pathol. u. Pharmakol. Bd. 139, S. 10, 1927.

23) Steiner, 1926, zit. nach Rigo u. Verzetsky (22).

24) Bossa, Boll. Soc. ital. Biol. sper. 3, 1114, 1928, ref. in Berichte uber d. ges. Physiol. u. exp. Pharmakol. Bd. 51, S. 607, 1929.

25) Farber, Zeitschr. f. d. ges. exp. Med. Bd. 49, S. 525, 1926.

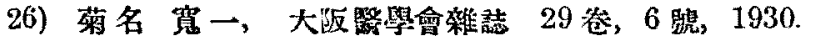

